\title{
CHANGES IN OCEAN HEAT, CARBON CONTENT, AND VENTILATION: REVIEW OF THE FIRST DECADE OF GLOBAL REPEAT HYDROGRAPHY (GO-SHIP)
}

30 May 2015

\section{Submitted to Annual Reviews of Marine Science 2016}

L. D. Talley, Scripps Institution of Oceanography, UCSD, La Jolla, CA, ltalley@ucsd.edu

R. A. Feely, NOAA/PMEL, Seattle, WA, Richard.A.Feely@noaa.gov

B. M. Sloyan, CSIRO, Hobart, Tasmania, Australia, Bernadette.Sloyan@csiro.au

R. Wanninkhof, NOAA/AOML, Miami, FL, Rik.Wanninkhof@noaa.gov

M. O. Baringer, NOAA/AOML, Miami, FL, Molly.Baringer@noaa.gov

J. L. Bullister, NOAA/PMEL, Seattle, WA, John.L.Bullister@noaa.gov

C. A. Carlson, University of California Santa Barbara, Santa Barbara, CA, carlson@lifesci.ucsb.edu

S. C. Doney, Woods Hole Oceanographic Institution, Woods Hole, MA, sdoney@whoi.edu

R. A. Fine, Rosenstiel School of Marine and Atmospheric Science, U. Miami, Miami, FL, RFine@rsmas.miami.edu

E. Firing, University of Hawai’i Manoa, Honolulu, HI, efiring@hawaii.edu

N. Gruber, Institute of Biogeochemistry and Pollutant Dynamics, ETH Zurich, Zurich, Switzerland, nicolas.gruber@env.ethz.ch

D. A. Hansell, Rosenstiel School of Marine and Atmospheric Science, U. Miami, Miami, FL, dhansell@rsmas.miami.edu

M. Ishii, JMA/MRI, Tsukuba, Japan, mishii@mri-jma.go.jp

G. C. Johnson, NOAA/PMEL, Seattle, WA, gregory.c.johnson@noaa.gov

K. Katsumata, JAMSTEC, Yokosuka, Japan, k.katsumata@jamstec.go.jp

R. M. Key, Princeton University, Princeton, NJ, key@princeton.edu

M. Kramp, JCOMMOPS, Ifremer, Brest, France, mkramp@jcommops.org 
C. Langdon, Rosenstiel School of Marine and Atmospheric Science, U. Miami, Miami, FL, clangdon@rsmas.miami.edu

A. M. Macdonald, Woods Hole Oceanographic Institution, Woods Hole, MA, amacdonald@whoi.edu

J. T. Mathis, NOAA/PMEL, Seattle, WA, Jeremy.Mathis@noaa.gov

E. L. McDonagh, NOC, Southampton, UK, e.mcdonagh@noc.ac.uk

S. Mecking, Applied Physics Laboratory, University of Washington, Seattle, WA, smecking@apl.washington.edu

F. J. Millero, Rosenstiel School of Marine and Atmospheric Science, U. Miami, Miami, FL, fmillero@rsmas.miami.edu

C. W. Mordy, Joint Institute for the Study of the Atmosphere and Ocean, University of Washington and NOAA/PMEL, Seattle, WA, calvin.w.mordy@noaa.gov

T. Nakano, JMA, Tokyo, Japan, nakano_t@met.kishou.go.jp

C. L. Sabine, NOAA/PMEL, Seattle, WA, Chris.Sabine@noaa.gov

W. M. Smethie, Lamont-Doherty Earth Observatory, Columbia University, Palisades, NY, bsmeth@ldeo.columbia.edu

J. H. Swift, Scripps Institution of Oceanography, UCSD, La Jolla, CA, jswift@ucsd.edu

T. Tanhua, Geomar, Germany, ttanhua@geomar.de

A. M. Thurnherr, Lamont-Doherty Earth Observatory, Columbia University, Palisades, NY, ant@ldeo.columbia.edu

M. J. Warner, University of Washington, Seattle, WA, warner@u.washington.edu

J.-Z. Zhang, NOAA/AOML, Miami, FL, jia-zhong.zhang@noaa.gov

Shortened running title: Ocean heat, carbon and ventilation change

Corresponding author: Lynne D. Talley, Scripps Institution of Oceanography, UCSD, 9500 Gilman Dr., La Jolla, CA 92093-0230 USA, ltalley@ucsd.edu 


\section{Table of contents}

1. Introduction

2. Heat and salinity

2.1 Deep ocean warming

2.2 Deep ocean salinity and freshwater changes

3. Circulation and diffusivities

3.1 Abyssal ocean circulation changes

3.2 Transport analyses and changes

3.3 Ocean mixing and vertical diffusivity

4. Carbon

4.1 Inorganic carbon inventories and fluxes

4.2 Dissolved organic carbon (DOC)

5. Ocean ventilation: Transient Tracers

5.1 Chlorofluorocarbons (CFCs), $\mathrm{SF}_{6}$, and Tritium- ${ }^{3} \mathrm{He}$

5.2 Radiocarbon ${ }^{14} \mathrm{C}$

6. Ocean ventilation: oxygen and nutrients

6.1 Oxygen

6.2 Nutrients

Supplemental Appendix 1: Organization and data policies of Global Ocean Ship-based Hydrographic Investigations Program (GO-SHIP)

S1. GO-SHIP: History and program goals and Supplemental Figure 1

S2. GO-SHIP Scientific Oversight

S3. Data types

S4. Data policies

S5. Future Science and Monitoring Objectives

S6. Summary 
Supplemental Appendix 2: Supplemental Figures 2 through 11 for Changes in ocean heat, carbon and ventilation (GO-SHIP)

\section{Key Words}

Anthropogenic climate change

Ocean temperature change

Salinity change

Ocean carbon cycle

Ocean oxygen and nutrients

Ocean chlorofluorocarbons

Ocean circulation change

Ocean mixing 


\begin{abstract}
The ocean, a central component of Earth's climate system, is changing. Given the global scope of these changes, highly accurate measurements of physical and biogeochemical properties need to be conducted over the full water column, spanning the ocean basins from coast to coast, and repeated every decade at a minimum, with a ship-based observing system. Since the late 1970s, when the Geochemical Ocean Sections Study (GEOSECS) conducted the first global survey of this kind, the World Ocean Circulation Experiment (WOCE) and Joint Global Ocean Flux Study (JGOFS), and now the Global Ocean Ship-based Hydrographic Investigations Program (GO-SHIP) have collected these "reference standard" data that allow quantification of ocean heat and carbon uptake, and variations in salinity, oxygen, nutrients, and acidity on basin scales. The evolving GOSHIP measurement suite also provides new global information about dissolved organic carbon, a large bioactive reservoir of carbon.
\end{abstract}

\title{
1. Introduction
}

The ocean is variable on all length and time scales. This variability has both natural and anthropogenic causes. For climate variability and climate change, the global ocean, through its full depth, is singularly important for its role in heat storage and mediation of increasing anthropogenic $\mathrm{CO}_{2}$ in the atmosphere. Single point time series stations have increased understanding of the patterns of temporal variability, but remain limited by their nature in the spatial domain. Satellite observations provide global coverage at relatively high temporal resolution, but are restricted to a few surface parameters. Autonomous floats have begun to provide nearly global coverage of temperature and salinity at 10-day intervals, but are currently limited to the upper $2000 \mathrm{~m}$ (Roemmich et al. 2015). A ship-based observing system is the only technique at present for obtaining the necessary, highly accurate measurements of physical and biogeochemical properties, including carbon. 
The Global Ocean Ship-based Hydrographic Investigations Program (GO-SHIP; http://go-ship.org) is a systematic re-occupation of select hydrographic sections (map in Supplemental Figure 1), with full-depth water column measurements of physical and chemical variables (see Supplemental Appendix 1). This program is a component of the Global Climate/Ocean Observing System (GCOS, GOOS).

Beginning with a comparison of two pairs of zonal hydrographic sections taken some 25 years apart in the North Atlantic (Roemmich \& Wunsch 1984), there has been ongoing documentation of the changing properties of the ocean, from the surface to the bottom. The data emerging from the decadal GO-SHIP program in combination with efforts from previous decades have led to major scientific discoveries that have advanced our understanding of the roles of the ocean in climate change, carbon cycling, and biogeochemical responses to climate change. The GO-SHIP results outlined herein have been key in studies of: a) heat and freshwater storage and flux (Section 2); b) circulation changes and mixing (Section 3); c) sequestration of anthropogenic carbon and biogeochemical changes (Section 4); d) deep and shallow water mass and ventilation (Section 5); e) oxygen and nutrient changes (Section 6); f) data for model calibration and validation; and g) calibration and checks of autonomous sensors.

\section{Heat and salinity}

The ocean plays a primary role in taking up and storing heat on our planet. Temporal and spatial variability in ocean heat storage is linked to decadally varying atmospheric forcing, and to the spatial pattern and variability of the ocean's overturning circulation (Section 3). As a result of increases in man-made greenhouse gases, the Earth's energy budget is currently not in balance, with more energy being absorbed than returned to space.

Quantifying the planetary energy imbalance is an important part of the projections of how much and how fast the atmosphere will warm (e.g. Frölicher et al. 2014), and anchors satellite measurements of the top-of-the-atmosphere energy imbalance (Loeb et al. 2012). Ocean warming has been estimated to have taken up 93\% of that energy imbalance from 1971-2010, with $3 \%$ each going into melting ice and warming the continents, and only $1 \%$ 
into warming the atmosphere (Rhein et al. 2013). The significance of the amount of heat stored in the deep ocean has become increasingly evident in the past several years (Purkey \& Johnson 2010; Mauritzen et al. 2012). While the upper ocean has taken up most of the excess heat, about $25 \%$ has gone into the deep (> $2000 \mathrm{~m}$ ) ocean.

Changes in Earth's heat balance are accompanied by changes in its water cycle. The ocean comprises $70 \%$ of the Earth's surface; most evaporation and precipitation occurs over the oceans. Seawater is a combination of fresh water and dissolved salts. The salts arise principally from weathering and the total amount in the ocean is effectively constant over millions of years. Therefore ocean salinity, proportional to mass of salt per mass of seawater, is principally a measure of dilution of the salts by fresh water. Ocean salinity distributions are set by the transport of freshwater through the atmosphere and ocean (e.g. Talley 2008).

Ocean salinity changes thus reflect variations in the hydrological cycle (evaporation, rainfall and river discharge) and in the cryosphere (e.g. sea-ice, glaciers, and ice-sheets). The ocean is effectively a global rain gauge because it covers so much of Earth. A global assessment of freshwater storage change using several decades of hydrographic data has shown coherent large-scale patterns (Boyer et al. 2005; Bindoff et al. 2007). This signal has been more clearly delineated by adding data from the upper ocean Argo profiling float network of the 2000s (Durack and Wijffels 2010). These changes are consistent with increased loss of freshwater from regions of net evaporation (mid-latitudes), and its deposition in regions of net precipitation (higher latitudes). Furthermore, a zonal redistribution of freshwater from the saline Atlantic and Indian oceans to the fresher Pacific has been documented (Bindoff et al. 2007; Durack et al. 2012). These are patterns expected in a warming climate (Rhein et al. 2013).

In the following summaries we focus on the deep (>2000 m) heat and salinity changes because these have only been observable using the multi-decadal repeat hydrography data. Changes in temperature and salinity in the abyssal ocean are a significant fraction of the overall changes, and result from changes in ventilation rates and properties of the waters that fill much of the deep global ocean (e.g. Johnson 2008). Heat and salinity changes contribute 
to global and regional sea level rise through thermal expansion and haline contraction; again the abyssal ocean contribution is not negligible (Kouketsu et al. 2011; Purkey \& Johnson 2013).

\subsection{Deep ocean warming}

GO-SHIP has revealed prominent warming in abyssal waters around the globe (Figure 1a). The strongest warming is observed in the Southern Ocean near the source of Antarctic Bottom Water (AABW) (Purkey \& Johnson 2010). When integrated globally, the abyssal temperature increase of order $0.03^{\circ} \mathrm{C}$ per decade in the deep basins around Antarctica amounts to about a 50 TW rate of warming below 2000 m between the 1990s and 2000s. This is roughly a quarter of the rate of warming of the entire climate system, which has been estimated to be about 183 TW between 1972 and 2008 (Church et al. 2011).

Regionally, warming has been strongest in the deep western boundary currents (Kouketsu et al. 2011; Sloyan et al. 2013), and more generally in the western regions of the basins. In the North Atlantic this pattern may be reversed, with warming on the western flank of the Mid-Atlantic Ridge (Johnson et al. 2008). Both patterns may imply a slowdown in the northward flow of abyssal water from Antarctica, as discussed in section 3.1. A third set of occupations of these sections, starting in 2012, has allowed quantification of deep ocean changes over longer time-periods, such as the abyssal warming in the Brazil Basin observed from 1989-2014 (Johnson et al. 2014).

\subsection{Deep ocean salinity and freshwater changes}

With GO-SHIP repeat hydrography, the full geographic and depth dependence of salinity changes has been observed. Salinity has increased in the subtropical salinity maxima of the South Indian and South Atlantic oceans. Near-surface freshening occurred in the Pacific subtropical salinity maxima (Nakano et al. 2015) and throughout the tropical Atlantic surface waters. The Southern Hemisphere pycnocline, at levels shallower than Antarctic Intermediate Water, has freshened (Talley 2009; Helm et al. 2010). This 
thermocline freshening is likely related to increased ventilation from the south, based on oxygen and chlorofluorocarbon (CFC) changes on the same sections (Sections 5 and 6.1).

Deep salinity changes reflect changes in deep and bottom water formation rates and properties, and, like temperature changes, they can affect sea level through changes in density. In the Southern Hemisphere, freshening of bottom waters throughout the Ross Sea and Adelie Land sectors has been observed from the 1990s through the 2000s, whereas the Weddell Sea salinity has changed very little (Figure 1b). The overall abyssal freshening for Antarctic Bottom Waters of $\theta<0^{\circ} \mathrm{C}$ is equivalent to the addition of about $100 \mathrm{Gt}^{-1}{ }^{-1}$ (a rate of about $0.003 \mathrm{~Sv}$ ) of freshwater (Purkey \& Johnson 2013) ( $1 \mathrm{Gt}=10^{12} \mathrm{~kg} ; 1 \mathrm{~Sv}=10^{9} \mathrm{~kg} / \mathrm{sec}$ ). This amount is a significant fraction of the increase in ice sheet melt there in recent years (e.g., Rignot et al. 2008), and the two changes may be related, with the ice melt freshening shelf waters that are a component of these bottom waters (e.g. Jacobs \& Guilivi 2010). Bottom water salinity decreased by as much as 0.06 PSS-78 between 1992 and 2011 in the Ross Bottom Waters adjacent to the continental rise, with a smaller decrease offshore (Swift \& Orsi 2012). Similar freshening is found, again strongest in the newly formed bottom waters, offshore of the Adelie Lands to the west from 1970 through 2012 (Katsumata et al. 2015).

Repeat hydrography also reveals decadal variability in the salinity of the various components of North Atlantic Deep Water (Yashayaev 2007), extending much deeper than the 2000-dbar reach of Argo, and often partly compensating the effect of temperature variations on density (and hence sea level) in this region. The shallower anomalies are linked to variations in strength of winter convection and Labrador Sea Water formation with changes in the North Atlantic Oscillation. Below 2000 m, observed decadal changes in the deep waters fed by the Iceland-Scotland Overflow are likely linked to changes in the properties and amount of Labrador Sea Water that is entrained during the turbulent overflow process, whereas the observed near-bottom Denmark Strait Overflow water variations are strongly interannual.

\section{Circulation and diffusivities}


The ocean circulation moves water thousands of kilometers horizontally, carrying heat, salt, freshwater, carbon, and nutrients. Within ocean basins, these wind-driven circulations comprise the Gulf Stream and Kuroshio gyre systems of the North Atlantic and North Pacific, and their counterparts in the Southern Hemisphere, namely the Brazil, Agulhas and East Australian Current systems. The eastward-flowing Antarctic Circumpolar Current system encircles Antarctica, connecting the ocean basins and their water properties.

Connected with this horizontal circulation is the ocean's overturning circulation, which involves changes in depth and density of water parcels. Much of the change in density occurs at the surface, resulting from the net heat and freshwater exchange with the atmosphere, combined with vigorous vertical and lateral mixing with adjacent waters. Below the surface mixed layer, motion is approximately along surfaces of constant density (isopycnals), but slow mixing within the stratified ocean interior gradually modifies water properties including density; on a large scale, water parcels drift across isopycnals. Because the maximum density of a water parcel tends to be close to its density when it leaves the mixed layer, the overturning circulations associated with tropical and subtropical gyres are relatively shallow. Waters below the pycnocline are ventilated from high latitudes. Deep waters are distributed globally by a horizontal circulation in which Deep Western Boundary Currents are prominent.

GO-SHIP and its predecessors are the principal source of information about changes in the shallow and deep overturning circulations, through measurements of properties associated with ventilation (sections 5 and 6 below) and through measurements of change in abyssal properties and water transports, described next.

\subsection{Abyssal ocean circulation changes}

The global overturning circulation transports heat, freshwater, and other water properties such as dissolved oxygen, nutrients, and carbon around the globe. Abyssal and deep flows 
are a major component of this circulation (Lumpkin \& Speer 2007; Talley 2013). The deep warming discussed in Section 2.1 corresponds to a contraction rate of about $8 \mathrm{~Sv}$ for Antarctic Bottom Waters of $\theta<0^{\circ} \mathrm{C}$ (Purkey \& Johnson 2012). A reduction in CFC inventories in the abyssal waters of the Weddell Sea (Huhn et al. 2013) suggests a significant decrease in ventilation rates in at least that sector of the Southern Ocean.

This reduction in AABW volumes (roughly a descent of $\theta=0^{\circ} \mathrm{C}$ at about $100 \mathrm{~m}$ per decade) appears to be associated with a reduction in northward flows of slightly warmer Lower Circumpolar Deep Water (LCDW) from the Southern Ocean through the South Pacific and South Atlantic oceans (Kouketsu et al. 2011). The assimilation of repeat hydrographic sections into a model by these investigators yields a slowdown in the northward transport of bottom waters of $0.7 \mathrm{~Sv}$ decade $^{-1}$ in the South Pacific and $0.4 \mathrm{~Sv}$ decade $^{-1}$ in the western South Atlantic from 1968 to 2005. The abyssal warming pattern in the South Pacific, with more warming at the western boundary (Sloyan et al. 2013), is consistent reduced eastward pressure gradient force near the bottom, and hence with reduced geostrophic northward flow. (The geostrophic balance, between the pressure gradient force and the Coriolis force, dominates ocean currents.)

In the North Pacific, an inverse model analysis using repeat hydrography data from 1985 and 2005 suggests a decrease of $1.5 \mathrm{~Sv}$ in northward transport of bottom waters of Southern Ocean derivation (Kouketsu et al. 2009). In the North Atlantic, analysis of five sections across $24^{\circ} \mathrm{N}$ occupied between 1981 and 2010 suggests that northward flow of bottom waters of Southern Ocean LCDW derivation is reduced by order $1 \mathrm{~Sv}$, although not monotonically (Frajka-Williams et al. 2011). This reduction of bottom-intensified northward flow over the Mid-Atlantic Ridge is consistent, again through geostrophic balance, with the deep pattern of warming on the western flank of the Mid-Atlantic Ridge and cooling to the west (Johnson et al. 2008).

While advection of changes in the LCDW in the Northern Hemisphere would take many decades, perhaps centuries, to be measurable in temperature and salinity, planetary waves can carry signatures of such changes all the way to the North Pacific in a few decades, as 
demonstrated by analysis of a global data assimilation of repeat hydrographic data (Masuda et al. 2010). Indeed, slight warming in very old bottom waters in the far northern Pacific has been observed with the highly accurate GO-SHIP measurements (Fukasawa et al. 2004) and attributed to this wave mechanism.

\subsection{Transport analyses and changes}

Measuring changes in ocean circulation, and the consequences of those changes for the Earth's heat and carbon budgets, is difficult; currents are highly variable on a broad range of temporal and spatial scales. Transport across hydrographic sections can be estimated using a combination of geostrophic calculations based on the density field, and direct measurements of currents. More robust estimates can be made by using the hydrographic and current measurements in inverse models. GO-SHIP's synoptic, decadal sampling is complemented by data sets with more frequent sampling and with more uniform spatial coverage,, such as sea surface height from satellite altimetry and Argo float velocity (e.g. Roemmich et al. 2007), or resource-intensive boundary current transport and mid-ocean arrays (e.g. Carton \& Hakkinen 2011) that provide direct velocity estimates. Ocean state estimations incorporating all of these available data sets are becoming useful circulation analysis tools (Wunsch \& Heimbach 2013b; Katsumata \& Masuda 2013).

In the Southern Hemisphere, the subtropical gyre circulations in the Indian and Pacific Oceans strengthened from the 1990s to the mid-2000s, based on hydrographic section transports and properties. Subtropical gyre strengthening in the Indian Ocean from 1987 to 2002 was documented using repeats of the $32^{\circ} \mathrm{S}$ section (Palmer et al. 2004). This was consistent with the observed signature of increased ventilation: increasing oxygen in the thermocline (McDonagh et al. 2005) and changes in upper ocean temperature and salinity, notably in the thick Mode Water layer (Bryden et al. 2003). In the South Pacific subtropical gyre, spinup was demonstrated using a combination of changes in sea surface height from satellite altimetry, mid-depth velocity field from Argo floats, and thermocline pressure gradient from repeated hydrographic data, in this case from a meridional section at $170^{\circ} \mathrm{W}$ that showed changes in the meridional gradient of surface 
dynamic height and thermocline depth (Roemmich et al. 2007). The strengthening was associated with increased westerly winds and stronger Ekman convergence, associated with an increasing Southern Annular Mode index (Thompson et al. 2000).

As part of the deep overturn of the global circulation, the Atlantic Meridional Overturning Circulation (AMOC) strength has been of interest for several decades. Increasingly robust indications of a mild decrease in its strength are reviewed in the Sidebar.

The meridional overturning circulation (MOC) strength in the Indian and Pacific Oceans is measured by the net northward transport in the deepest layers, which therefore warms, upwells diapycnally, and returns southward at lower density. For the MOC in the Southern Hemisphere Indian Ocean, the difference in transport assessed from the same $32^{\circ} \mathrm{S} 1987-2002$ repeats was within the large range of uncertainty, using geostrophic calculations from the CTD profiles with Lowered Acoustic Doppler Current Profiler (LADCP) velocities as an initial reference for the 2002 section (McDonagh et al. 2008).

Southern Ocean repeat sections in the 1990's and 2000's and direct velocity from Argo float drift were used in a box inverse model to estimate the Southern Ocean Circulation and compare with ocean models (Katsumata \& Masuda 2013). They found that the MOC strength as measured by the northward transport of the bottom water decreased in the ocean models, which was consistent with the inverse box model, within the uncertainties. Part of the weakening is explained by the deep warming discussed in Section 3.1.

In contrast, transport of the eastward Antarctic Circumpolar Current has shown no significant change despite several decades of strengthening westerly winds (e.g. increase in the Southern Annular Mode index), based on comparison of hydrographic data between the 1990s (WOCE) and 2000s (GO-SHIP) (Katsumata \& Masuda 2013).

\subsection{Ocean mixing and vertical diffusivity}


The ocean's vertical and lateral distributions of heat, salt and tracers are maintained not only by advection from source regions but also by ocean mixing, both across isopycnals (diapycnal) and along isopycnals. The latter has been the focus of the CLIVAR DIMES experiment (LaCasce et al. 2014) and is not summarized here. Closing the ocean's overturning circulation requires diapycnal mixing to flux heat and buoyancy downward, reducing the density of deep waters as they gradually move upwards (e.g. Munk 1966; Sloyan \& Rintoul 2001; Talley 2013). Space- and time-averaged diapycnal transports associated with the ocean's large-scale overturning circulation may be diagnosed from basin-scale heat, salt and tracer budgets using hydrographic sections, yielding estimates of diapycnal diffusivity (e.g. Ganachaud \& Wunsch 2001; Lumpkin \& Speer 2007; Macdonald et al. 2009; Huussen et al. 2012).

Direct observations of diapycnal diffusivity from microstructure measurements, which are rare, have been essential for deriving a 'finestructure' parameterization of dissipation and diffusivity (Gregg 1989; Polzin et al. 1995; Gregg et al. 2003). With this parameterization, spatial patterns of mixing can be estimated from the much more numerous CTD and LADCP profiles, as are collected in GO-SHIP. The relationship between internal-wave shear/strain and turbulence presumes a cascade of energy from longer to shorter internal waves and turbulence (Henyey et al. 1986). In dynamically quiet regions away from boundaries and strong currents, finestructure parameterizations are accurate to within about a factor of two (Polzin et al. 2014; Whalen et al. 2015). Regional and global patterns of turbulence and mixing have been mapped (e.g., Naveira Garabato et al. 2004; Sloyan 2005; Kunze et al. 2006; Whalen et al. 2012).

A significant finding is that in most ocean basins the vertical distribution of diapycnal diffusivity and dissipation has two maxima (e.g. Supplemental Figure 2): one in the upper ocean (200-1000m), and the other within $1500 \mathrm{~m}$ of the sea floor (Kunze et al. 2006;

Huussen et al. 2012; Waterhouse et al. 2014). Diffusivities are low $\left(<10^{-5} \mathrm{~m}^{2} / \mathrm{s}^{2}\right)$ in large regions of the ocean's thermocline. Diapycnal diffusivity is consistently high $\left(>10^{-4}\right.$ $\mathrm{m}^{2} / \mathrm{s}^{2}$ ) over rough topography where breaking internal waves, driven by tidal and other forces including deep strong currents, cause turbulence, as well as in regions of high 
kinetic energy. Using repeated hydrographic sections, Sheen et al. (2014) find that the temporal variability of abyssal mixing in the Southern Ocean between 1993 and 2014 has been dominated by modulation due to mesoscale eddies, rather than any detectable longterm trend.

Quantitative comparisons between the diapycnal transport and observed mixing are, however, not yet satisfactory (Huussen et al. 2012). It is possible we underestimate mixing near topography and we do not understand the nature of diapycnal mixing in the equatorial band (Whalen et al. 2012).

Results from finestructure parameterization methods applied to repeat hydrography data are contributing to new parameterizations of mixing in global-scale ocean circulation models (Decloedt \& Luther 2012; Melét et al. 2013). These can affect the nature of deep circulation, deep overturning, and water properties from the thermocline to the abyss, and hence the ability of ocean models to capture response to changing surface forcing.

\section{Carbon}

\subsection{Inorganic carbon inventories and fluxes}

The global ocean has continued to take up a substantial fraction of the anthropogenic $\mathrm{CO}_{2}$ $\left(C_{a n t}\right)$ emissions from fossil fuel combustion and net land-use change since the 1990s, thereby constituting a major mediator of global climate change. General ocean circulation models and data-constrained models suggest that the ocean absorbed approximately 37 Pg C of $C_{a n t}$ between 1994 and 2010 (Khatiwala et al. 2013; map in Figure 2), increasing the $\mathrm{C}_{\text {ant }}$ inventory from $118 \pm 20 \mathrm{Pg} \mathrm{C}$ to $155 \pm 31 \mathrm{Pg} \mathrm{C}$. This amounts to a mean annual uptake rate of about $2.3 \mathrm{Pg} \mathrm{C} \mathrm{yr}^{-1}$ or about $27 \%$ of the total anthropogenic $\mathrm{CO}_{2}$ emissions over this time period. However, this globally critical estimate is based on numerical techniques using transient tracers and has not been independently verified using ocean carbon observations. The sustained repeated occupations of many of the lines measured during the 1990s and 2000s provide an observation-based uptake estimate. 
Changes in dissolved inorganic carbon (DIC) concentration between repeat occupations reflect both anthropogenic carbon $\mathrm{C}_{\text {ant }}$ uptake and natural variations in circulation and organic matter remineralization (e.g. Sabine \& Tanhua 2010). Several methods have been developed and tested to accomplish this separation along repeat sections (e.g., the extended multi-linear regression (eMLR) method (Friis et al. 2005)), and recently eMLR has been extended to permit basin-wide estimates of $\mathrm{C}_{\text {ant }}$ trends utilizing data from repeat occupations and climatological data from the World Ocean Atlas (Clement \& Gruber, personal communication).

Preliminary global-scale results from this modified eMLR method indicate a $\mathrm{C}_{\text {ant }}$ uptake

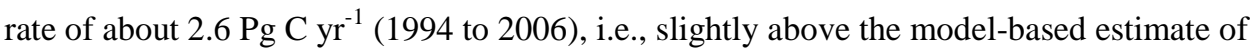
2.3 Pg C $\mathrm{yr}^{-1}$ (Khatiwala et al. 2013). However, the large uncertainty of this preliminary estimate of $\pm 0.5 \mathrm{Pg} \mathrm{C} \mathrm{yr}^{-1}$ precludes any statement with regard to the significance of this difference. Kouketsu and Murata (2014) estimated an even higher storage rate of 2.9 \pm 0.4 $\mathrm{Pg} \mathrm{C} \mathrm{yr}^{-1}$ for the most recent decade based on observations and utilizing the $\Delta \mathrm{C}^{*}$ method of Gruber et al. (1996). Based on GO-SHIP reference and high-frequency sections, Takatani et al. (2014) documented that the rate of $\mathrm{C}_{\mathrm{ant}}$ increase on the isopycnals in the western North Pacific subtropical gyre is consistent with that expected from the atmospheric $\mathrm{CO}_{2}$ increase, Revelle factor, and the CFC age. The mean rate of $\mathrm{C}_{\text {ant }}$ inventory change over the past decades varied from $0.22 \pm 0.05 \mathrm{~mol} \mathrm{~m}^{-2}$ year ${ }^{-1}$ to $0.94 \pm 0.10 \mathrm{~mol} \mathrm{~m}^{-2}$ year $^{-1}$ depending on the depth to which the ocean is ventilated. Deep Western Boundary Currents serve as important ventilation pathways and carry an appreciable amount of anthropogenic carbon into the interior. The western basins of the North and South Atlantic and North Pacific show significantly higher $\mathrm{C}_{\text {ant }}$ inventories and storage rates than the eastern basins (Körtzinger et al. 1999; Murata et al. 2008; Brown et al. 2010; Waters et al. 2011).

Substantial temporal differences in $\mathrm{C}_{\text {ant }}$ storage rates have been observed on decadal and sub-decadal time scales (Wanninkhof et al. 2010; 2013a; Sabine \& Tanhua 2010; Khatiwala et al. 2013; Tanhua et al., 2013a) (Figure 3); temporal variability in $\mathrm{C}_{\text {ant }}$ of similar magnitude and pattern is also found in numerical simulations highlighting the 
need to integrate repeat section occupations with other data and model information (Levine et al. 2008). Pérez et al. (2010) found that the $C_{a n t}$ storage rate in the North Atlantic was dependent on the North Atlantic Oscillation (NAO), with highest $\mathrm{C}_{\text {ant }}$ storage rates occurring during the positive phase of NAO consistent with model studies linking NAO-driven increases in mode water formation to enhanced transport of $\mathrm{C}_{\text {ant }}$ from surface water into the ocean interior (Levine et al. 2011). Furthermore, Pérez et al. (2013) showed a decrease in uptake from 1990 to 2006 that was attributed to weakening of the MOC. In the Pacific Ocean, there are higher $\mathrm{C}_{\text {ant }}$ storage rates in the South Pacific as compared with the North Pacific (Murata et al. 2007; Sabine et al. 2008). In the Indian Ocean, the largest $C_{a n t}$ storage rates are observed south of the equator where $C_{a n t}$ increases have been observed to $1800 \mathrm{~m}$ (Murata et al. 2010). A number of studies that used observations from hydrographic sections have indicated that the Southern Ocean may be responsible for as much as $30-40 \%$ of the global $C_{\text {ant }}$ uptake (e.g., Gruber et al. 2009; Khatiwala et al. 2009). There is still debate as to whether this uptake is stored or exported (Sabine et al. 2004; van Heuven et al. 2011) and in what water masses (e.g., Gruber et al. 1996; Sabine et al. 2004; van Heuven et al. 2011; Pardo et al. 2014). Both carbon parameters and other tracers (e.g., $\mathrm{CFCs}, \mathrm{CCl}_{4}$ and ${ }^{39} \mathrm{Ar}$ ) from these cruises are being used to investigate the possibilities.

Ocean interior carbon observations also provide a constraint on decadal average net seaair $\mathrm{CO}_{2}$ flux of both natural and anthropogenic $\mathrm{CO}_{2}$ through ocean inversion procedures, provided one knows the ocean's circulation and mixing well (Gloor et al., 2003). Using an ensemble of 10 general circulation models and inorganic carbon data from the 1990s and 2000s, including GO-SHIP, Gruber et al. (2009) estimated the net sea-air flux of $\mathrm{CO}_{2}$ over 23 regions globally (Supplemental Figure 3). They found a remarkable level of agreement with sea-air $\mathrm{CO}_{2}$ fluxes inferred from surface ocean $\mathrm{pCO}_{2}$ measurements

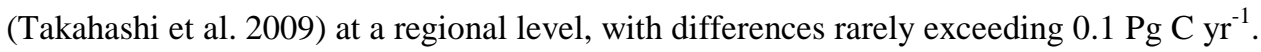

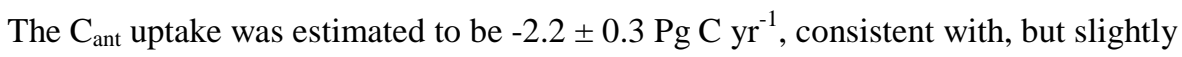
higher, than the estimate based on surface sea-air $\mathrm{CO}_{2}$ fluxes (Takahashi et al. 2009; Wanninkhof et al. 2013b; Landschützer et al. 2014). 
The uptake of anthropogenic $\mathrm{CO}_{2}$ from the atmosphere into the ocean interior has also resulted in ocean acidification, that is, a long-term decrease in $\mathrm{pH}$ since the beginning of the industrial era, of up to 0.1 in surface waters (e.g. Feely et al 2009). Feely et al. (2004) showed how the increased $\mathrm{CO}_{2}$ reduced aragonite and calcite saturation state of the global ocean. This effect of elevated atmospheric $\mathrm{CO}_{2}$ has been illuminated by results from GO-SHIP and the previous hydrographic sampling programs (Feely et al. 2004; 2009; Sabine et al. 2004; Key et al. 2004), showing pH declines in the surface water of about -0.002/yr from 1991 to 2006 along sections in the North Pacific (summary in Rhein et al. 2013). The GLODAP data product included estimates of the preindustrial DIC concentration derived by differencing the measured DIC and the estimated anthropogenic component. Orr et al. (2005) used these data along with models to investigate globalscale ocean acidification on 100-year time scales. Yool et al. (2013) used GLODAP values and World Ocean Atlas data to estimate the $\mathrm{pH}$ change from the preindustrial to the present (Supplemental Figure 4). The smallest changes (-0.04 to -0.06$)$ are in the tropics and subtropics. The greatest $\mathrm{pH}$ decreases $(-0.08$ to -0.1$)$ are in the northern North Atlantic and North Pacific, and in a circumpolar band in the Southern Ocean.

\subsection{Dissolved organic carbon (DOC)}

Dissolved organic carbon (DOC) is one of the largest bio-reactive pools of carbon in the ocean (Hansell et al. 2009, 2012). Over the past decade, time-series and basin-scale observations ( 50,000 data points) have revealed temporal and spatial variability of DOC in unprecedented detail (Figure 4); from this detail, we are able to infer the processes controlling the variability. We now estimate the inventory of oceanic DOC to be $\sim 662 \pm$ $32 \mathrm{Pg}\left(10^{15} \mathrm{~g}\right) \mathrm{C}$, a mass exceeding organic carbon in suspended particles by 200 -fold, but about 50 times less than the total DIC inventory.

The bulk DOC pool contains a myriad of compounds that turn over on time scales from seconds to millennia (Hansell et al. 2012; Carlson \& Hansell 2015). The majority of the newly produced DOC is rapidly remineralized by heterotrophic bacterioplankton within the ocean’s surface layer (Carlson \& Hansell 2015). However, 20\% of global net 
community production ( $1.9 \mathrm{Pg} \mathrm{C} \mathrm{yr}^{-1}$ ) escapes rapid microbial degradation for periods long enough to be exported from the euphotic zone via convective mixing or isopycnal exchange into the ocean's interior (Copin-Montgut \& Avril 1993; Carlson et al. 1994; Hansell et al. 2009). DOC export occurs with mode water and deep-water formation in the North Atlantic (Figure 4) as mid-latitude, warm, DOC-enriched surface waters are transported with surface currents to subpolar and high latitudes. Here, convective overturn transports the DOC deep into the interior where it is slowly removed through southward flow.

Previously, estimating the removal rates of exported DOC within the ocean's interior had not been possible due to the slow decay rates of the biologically recalcitrant DOC.

However, coupled measures of bulk DOC, DOC characterization, water mass age tracers, and other biogeochemical variables (Hansell et al. 2009; 2012; Carlson et al. 2010; Goldberg et al. 2011) obtained by the GO-SHIP program have greatly improved our understanding of bulk DOC distribution, fractions of DOC lability, and export (Hansell et al. 2012; Hansell 2013). For example, linear and multiple linear regression models applied to pairwise measurements of DOC and CFC-12 ventilation age, retrieved from major water masses within the main thermocline and North Atlantic Deep Water (A16, A20, A22), allow estimates of decay rates for exported DOC ranging from 0.13 to 0.94

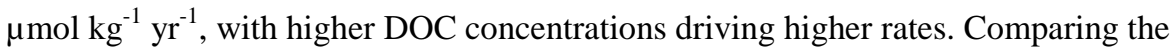
change in DOC to change in oxygen in the same water masses suggests that DOC oxidation contributes 5 to $29 \%$ of the apparent oxygen utilization in the deep water masses of the North Atlantic (Carlson et al. 2010).

Measurements of carbohydrate and dissolved combined neutral sugar (DCNS) concentrations allow us to further assess the change in chemical character along meridional transects in the North Atlantic (A20) and South Pacific (P16S). As microbes remineralize dissolved organic matter (DOM), they preferentially remove the most labile components of DOM such as carbohydrates and DCNS, leaving behind more recalcitrant components. Data collected from the hydrographic sections reveal systematic diagenetic patterns of DOM across ocean basins (Goldberg et al. 2011), providing further insight of 
the roles that stratification, ventilation, export, and subsequent remineralization play in DOM quality.

\section{Ocean ventilation: Transient Tracers}

\subsection{Chlorofluorocarbons (CFCs), $\mathrm{SF}_{6}$, and Tritium- ${ }^{3} \mathrm{He}$}

Anthropogenic transient tracer distributions provide insight into the pathways, rates and temporal variations in the processes ventilating the ocean on decadal time scales (Johnson et al. 2008; Wanninkhof et al. 2013b). Chlorofluorocarbon (CFC), sulfur hexafluoride $\left(\mathrm{SF}_{6}\right)$, and bomb tritium have been entering the ocean since the middle of the $20^{\text {th }}$ century (Supplemental Figure 5), during which time the ocean has taken up about two thirds of its anthropogenic carbon inventory. CFC and tritium- ${ }^{3} \mathrm{He}$ data, especially as used with transit time distributions (TTD; see below), have played a key role in reconstructing the complex spatial and temporal evolution of anthropogenic $\mathrm{CO}_{2}$ in the global ocean (Tanhua et al. 2008; Khatiwala et al. 2009; Wanninkhof et al. 2013a; Sabine \& Tanhua 2010), in estimating apparent oxygen utilization rates (Jenkins 1977; Stanley et al. 2012; Sonnerup et al. 2013, 2015), and separating observed changes in oxygen and nutrients into physical (e.g., solubility, circulation, mixing) and biological processes (Jenkins 1998; Emerson et al. 2001; Mecking et al. 2006; Sonnerup et al. 2013; 2015). Transient tracers have also been used in testing and evaluating a variety of global ocean circulation and biogeochemical models (Dutay et al. 2002; Matsumoto et al. 2004; Peacock et al. 2005; Hartin et al. 2014; Long et al. 2014).

Ventilation rates of a water mass can be estimated using transient tracer-derived ages, measures of the elapsed time since last contact with the surface ocean. The wellcharacterized atmospheric histories of the CFCs and $\mathrm{SF}_{6}$ (Walker et al. 2000; Bullister 2014), along with the solubility of these gases in seawater (Warner \& Weiss 1985; Bullister et al. 2002), allow the equilibrium concentrations of these compounds in the surface ocean, and thus newly subducted waters, to be modeled as a function of time (e.g., Tanhua et al. 2013b). The Montreal Protocol resulted in peak atmospheric CFC-11 and 
CFC-12 concentrations in the late 1990s and early 2000s, respectively, followed by a slow decrease, while $\mathrm{SF}_{6}$ has been increasing in the atmosphere at 5-7\% per year for the past 2-3 decades (Supplemental Figure 5). Decay of tritium to ${ }^{3} \mathrm{He}$ provides an additional radioisotope natural clock for the isolation of water parcels from the atmosphere (Jenkins 1977).

Tracer ages are modified by mixing and complicated by the nonlinear source functions (e.g., Doney et al. 1997; Mecking et al. 2006; Waugh et al. 2013; Tanhua et al. 2013b). A commonly used technique, TTDs, assumes that the tracer age is composed of a spectrum of ages. The addition of $\mathrm{SF}_{6}$ provides improved estimates of mixing of different water parcels. Two TTD methods have been used, the inverse Gaussian method which assumes a 1-D advection-diffusion process (e.g., Waugh et al. 2003; 2013) and the maximum entropy method, which relaxes this assumption and provides information on water mass composition as well as ages (Holzer et al. 2010). Both methods can include natural radiocarbon, which provides temporal information for water formed prior to the transient tracer invasion.

The global thermocline is well ventilated on the time scale of the $\mathrm{CFC} \mathrm{SF}_{6}$ and bombtritium transient, while deeper isopycnal surfaces are much less ventilated (Figure 5 and Supplemental Figure 7). CFC-12 decadal differences in Figure 5 show the invasion of the time-dependent signal into the thermocline, with greatest increases at the front of the pulse of the tracer. Regions of the ocean where pCFC ages in the thermocline exceed several decades include the deep portions of oxygen minimum zones and the northern Indian Ocean thermocline. CFC distributions, as presented in the WOCE Hydrographic Programme Atlases, reveal well-ventilated deep and bottom waters in the Southern Ocean (WOCE Hydrographic Programme Atlas http://woceatlas.ucsd.edu/index.html) and North Atlantic (LeBel et al. 2008).

Models of climate change predict that increased stratification should lead to decreased ventilation. Such an effect is seen in the Northern Hemisphere subtropics and subpolar thermoclines, and also in the Antarctic Circumpolar Current, where predicted CFCs 
based on TTDs were lower than predicted, and oxygen declined (Figure 5). However, decadal trends in the subtropical gyres of the Southern Hemisphere indicate increased ventilation for the deep thermocline. The observed increase in Southern Hemisphere subtropical thermocline CFC-11 and CFC-12 concentrations compared to the 1990s (Figure 5) has been greater than predicted by either models or TTDs, and tracer ages have decreased (Fine et al. 2014; Waugh et al. 2013; Figure 5 and Supplemental Figure 7). Thermocline oxygen increases (Section 6.1; McDonagh et al. 2005; Talley 2009; Mecking et al. 2012) have been associated with increasing ventilation due to changes in the Southern Annular Mode (Roemmich et al. 2007) that were reflected in increasing CFC concentrations in the lower thermocline (Fine 2011). Both oxygen and TTDs lead to the same conclusion - an increase in ventilation rates in southern subtropical gyres, which has reversed in recent years based on the most recent oxygen distributions (Section $6.1)$.

Transient tracer inventory calculations (Orsi et al. 2002; Smethie \& Fine 2001; Rhein et al. 2002; LeBel et al. 2008; Smethie et al. 2007) provide integral water mass formation rates for deep-water masses (Hall et al. 2007). As an example, North Atlantic CFC-12 inventory changes over the period 1997-2005 showed a reduction in classical Labrador Sea Water (LSW) formation (Rhein et al. 2011) while upper LSW formation increased (Kieke et al. 2006; 2007). Decreased classical LSW formation was accompanied by a decreased subpolar gyre transport index (Curry \& McCartney 2001; Kieke et al. 2007; Rhein et al. 2011) and decreased strength of the subpolar gyre from altimeter analysis (Hakkinen \& Rhines 2004; Hakkinen et al. 2008). CFCs confirm the importance of the DWBC as an advective pathway into the subtropics, while interior CFC concentrations support the importance of interior pathways that are related to the role of eddies and winds (Lozier 2010). This is consistent with the DWBC-deep interior tritium- ${ }^{3} \mathrm{He}$ data from TTO (Doney \& Jenkins 1994).

\subsection{Radiocarbon ${ }^{14} \mathrm{C}$}


Oceanic radiocarbon, ${ }^{14} \mathrm{C}$, is both a transient and a natural tracer, experiencing decadal change due to atmospheric nuclear weapons testing in the 1950s and 1960s. The bomb radiocarbon spike elevated the atmospheric ${ }^{14} \mathrm{C}$ level by a factor of 2 and was sufficiently large to be easily measured as it moved into the upper ocean and finally toward the abyss. Like anthropogenic $\mathrm{CO}_{2}$, the distribution of bomb-radiocarbon is varying on a background of natural ${ }^{14} \mathrm{C}$. Improved measurement technology has reduced sample size requirements by a factor of 1000 relative to the initial high-quality survey (mid-1970s) and measurement precision has improved by a factor of 2. Key et al. (2004) produced the first global 3-D maps of the distribution of measured, background, and bomb-produced radiocarbon. These maps were then integrated to yield inventories. The 2000s GO-SHIP sections have extended the time series, have been incorporated in GLODAPv2 (Olsen et al. 2014), and have allowed us to monitor the bomb spike as it is mixed into the ocean (Figure 6 and Supplemental Figures 8 and 9).

Radiocarbon maps and inventories have been used for global mean air-sea exchange rates for $\mathrm{CO}_{2}$ (Sweeney et al. 2007; Naegler et al. 2006), calibration of global ocean general circulation models, and ocean ventilation rates (Matsumoto et al. 2004). More recently, Graven et al. (2012) have demonstrated that the temporal changes in ocean interior ${ }^{14} \mathrm{C}$ provide important independent constraints on the oceanic uptake of anthropogenic $\mathrm{CO}_{2}$. This is because in recent decades, the oceanic uptake of ${ }^{14} \mathrm{C}$ (Figure 6) is largely controlled by ocean circulation and mixing, and no longer by air-sea gas exchange, as was the case in the early decades after the bomb spike.

\section{Ocean ventilation: oxygen and nutrients}

\subsection{Oxygen}

Systematic and large changes in oxygen, mostly reductions, have been documented over the last two decades through GO-SHIP repeat hydrography and local station time series (e.g. Keeling et al. 2010). The oxygen changes indicate large-scale changes in ventilation, temperature, as it impacts oxygen solubility, and possibly remineralization, which can 
impact ecosystem health. Some of the observed oxygen changes could be due to changes in biology, but the consensus is that physical changes usually predominate, based on modeling studies (Deutsch et al. 2005) and correlations with physical forcing such as the NAO (Johnson \& Gruber 2007). Combination of oxygen data with transient tracer data provides further evidence regarding the time scales at which the ventilation changes occur (Section 2.5). Combination of oxygen data with carbon data (e.g. Sabine et al. 2008) and pH data (e.g. Byrne et al. 2010) has allowed separation of DIC/pH changes along repeat sections into anthropogenic and ventilation/remineralization components, including their respective effects on carbon storage and ocean acidification.

The deoxygenation in the open-ocean thermocline over the past two decades is consistent with the expectation that warmer waters will hold less dissolved oxygen (solubility effect), and that warming-induced stratification leads to a decrease in the transport of dissolved oxygen from surface to subsurface waters (stratification effect) (Matear \& Hirst 2003; Deutsch et al. 2005; Frölicher et al. 2009). About 15\% of the oxygen decline between 1970 and 1990 can be explained by warming and the remainder by increased stratification (Helm et al. 2011).

Oxygen decline is found most consistently in the oxygen minimum zones of the tropical Pacific, Atlantic, and Indian oceans, and in the subpolar and subtropical North Pacific and North Atlantic (Stramma et al. 2010, 2012; Johnson \& Gruber 2007; Keeling et al. 2010; Keeling \& Manning 2014). Differences between GO-SHIP and WOCE oxygen on mid-ocean meridional sections show these Northern Hemisphere declines, and also a decline within the Antarctic Circumpolar Current thermocline in the far south, as in Aoki et al. (2005) (Figure 5).

Analyses in the North Atlantic over more than 50 years paint a more varied picture. While the upper, mode, and intermediate waters are indeed losing oxygen, driven by changes in solubility, the deeper waters actually gained oxygen over this period due to changes in circulation and ventilation (Stendardo et al. 2012). The trend in the North Pacific is based on a $>50$-year time series of oxygen data at Ocean Station P, which 
shows large bi-decadal cycles on top of the smaller long-term trend $\left(0.39-0.70 \mu \mathrm{mol} \mathrm{kg}{ }^{-1}\right.$ $\mathrm{yr}^{-1}$; Whitney et al. 2007), and on a 30 -year time series data in the Oyashio off northern Japan, which also shows large bi-decadal cycles on the long-term trend $(0.9 \pm 0.5 \mu \mathrm{mol} \mathrm{kg}$ ${ }^{1} \mathrm{yr}^{-1}$; Ono et al. 2001). The North Pacific GO-SHIP cruises have been instrumental in determining the spatial extent of the decadal-scale variations that extend into the subtropics in the east (e.g., Emerson et al. 2004; Mecking et al. 2008) and in the west (Kouketsu et al. 2010; Takatani et al. 2012; Sasano et al. revised).

In contrast to the oxygen declines in many regions, the subtropical Southern Hemisphere thermocline experienced oxygen increases over the past decades. At $32^{\circ} \mathrm{S}$ in the Indian Ocean, McDonagh et al. (2005) found a substantial increase in oxygen from 1987 to 2002, reversing an oxygen decline observed earlier (Bindoff \& McDougall 2000) (Supplemental Figure 10). An oxygen increase also occurred over similar time periods along the $30^{\circ} \mathrm{S}$ repeat sections in the Pacific and Atlantic oceans (Talley 2009). This oxygenation of the subtropical thermocline likely resulted from increased ventilation due to spin-up of the Southern Hemisphere gyres (Sections 3.2 and 5.1), documented at least for the Pacific Ocean based on dynamic height changes (Roemmich et al. 2007). The most recent 2009 repeat of the I5 section, however, indicates yet another reversal in gyre conditions with oxygen decreasing (Mecking et al. 2012) in response to natural decadal variability as well as anthropogenic climate change (Kobayashi et al. 2012).

\subsection{Nutrients}

Understanding of basin-scale processes governing nutrients and oxygen has been greatly enhanced through nutrient-based geochemical studies. A linear combination of nitrate $(\mathrm{N})$ and phosphate $(\mathrm{P})$, defined as $\mathrm{N}^{*}$, provides an estimate of excess nitrogen (e.g. nitrogen fixation, atmospheric deposition) or nitrogen deficit (e.g. denitrification, anammox) relative to global Redfield stoichiometry, and is widely used for mapping the nitrogen cycle (Supplemental Figure 11). Use of $\mathrm{N}^{*}$ has contributed to an upward revision of global estimates of nitrogen fixation (Moore and Doney, 2007). Another geochemical tracer, $\mathrm{Si}^{*}$, the difference between silicic acid and nitrate concentrations, has shown the 
importance of Southern Ocean nutrient supply to the global thermocline north of $30^{\circ} \mathrm{S}$ (Sarmiento et al. 2004).

Nutrient changes observed over the past several decades have been attributed to: (i) physical stratification and wind changes that also affect oxygen (section 6.1), and (ii) human activity, mainly fossil-fuel combustion and fertilizer production, that has increased atmospheric deposition and riverine discharge of $\mathrm{N}$ to the ocean, thereby impacting the ocean biological carbon pump (Doney 2010).

(i) Based on projected sea surface temperature change, enhanced stratification is projected for the future ocean that could reduce surface ocean nutrient availability and tropical/subtropical oceanic primary production (Kamykowski \& Zentara 2005). Over the past several decades, Whitney et al. (2013) observed decreasing oxygen and increasing nutrients below the pycnocline in the subarctic Pacific Ocean, forced by changes in the advective flux of oxygen and nutrients, surface production and export, and remineralization. Interestingly, the vertical flux of nutrients to the euphotic zone remained relatively stable because increasing nutrient concentrations below the pycnocline offset an increase in pycnocline stratification. The long-term trends can be obscured by large interannual and multi-decadal fluctuations in upper ocean nutrient distributions that are coupled with climate modes of variability (Di Lorenzo et al. 2009; Henson et al. 2010).

(ii) Atmospheric deposition of anthropogenic $\mathrm{N}$ in the western North Pacific has been associated with increasing excess $\mathrm{N}$ in the upper water column in last 30 years, determined from $\mathrm{N}^{*}$ and CFC-based ventilation rates (Kim et al. 2014). The effect was highest close to Asia, a source region for reactive $\mathrm{N}$, with rates decreasing eastward across the North Pacific. This input may eventually transform this ecosystem from $\mathrm{N}$ to $\mathrm{P}$ limitation (Kim et al. 2014). In the North Atlantic subtropical gyre, rates of atmospheric $\mathrm{N}$ deposition are comparable to estimated $\mathrm{N}_{2}$ fixation, but reactive $\mathrm{N}$ is rapidly consumed and does not accumulate in surface waters (Zamora et al. 2010). Instead, excess N is 
accumulating in the main thermocline with 15-20\% attributable to atmospheric deposition (Zamora et al. 2010; Hansell et al. 2007).

To detect long-term climate trends in the presence of natural variability and current nutrient data uncertainty will require many decades of sustained observation as well as improved measurement accuracy during GO-SHIP cruises (Zhang et al 2000), including use of nutrient Certified Reference Materials.

\section{Summary Points}

Significant climate-related results based largely on GO-SHIP data compared with data from earlier decadal global hydrographic surveys include:

- The ocean is warming, taking up the majority of the excess heat in the Earth system over recent decades; about a quarter of it is below $2000 \mathrm{~m}$.

- Abyssal waters originating in the Southern Ocean have been warming; those from the Pacific and Indian sectors have also been freshening.

- Vertical diffusivity increases from a minimum in the thermocline to a maximum within the bottom $1500 \mathrm{~m}$ in many regions.

- Increased stratification has resulted in a decline in oxygen and increase in nutrients in the Northern Hemisphere thermocline, and an expansion of the tropical oxygen minimum zones. Southern Hemisphere thermocline oxygen increased in the 2000s due to stronger wind forcing.

- Anthropogenic carbon uptake has been quantified and mapped; the oceans currently sequester about $27 \%$ of the anthropogenic carbon released to the atmosphere by fossil fuel burning and land-use change.

- As anthropogenic $\mathrm{CO}_{2}$ invades the ocean, the upper ocean is acidifying.

- Dissolved organic carbon, a large, bioactive reservoir, has been mapped and inventoried for the first time, and its contribution to export production ( 20\%) and deep ocean oxygen utilization quantified. 
- Atmospheric and riverine input of anthropogenic nutrients has changed ocean biogeochemistry in the upper waters of the western North Pacific and the thermocline of the North Atlantic.

\section{Future Issues}

Sustaining the ship-based, full-depth ocean observations coordinated through GO-SHIP is of high priority, particularly since we anticipate accelerating changes in the coming decades.

GO-SHIP evolves with experience and with new technology. We look forward to incorporating advances in biological and biogeochemical sensing techniques that will expand the role of GO-SHIP in documenting long-term changes in marine biogeochemistry and ecosystems.

\section{Related Resources}

Feely RA, Fabry VJ, Dickson AG, Gattso J-P, Bijma J, Riebesell U, Doney S, Turley C, Saino T, Lee K, Anthony K, Kleypas J. 2010. An international observational network for ocean acidification. Proceedings of OceanObs'09: Sustained Ocean Observations and Information for Society (Vol. 2). ed. J Hall, DE Harrison, D Stammer, Venice, Italy, ESA Publication WPP-306, doi:10.5270/OceanObs09.cwp.29

GO-SHIP. 2015. The Global Ocean Ship-Based Hydrographic Investigations Program. http://www.go-ship.org

Hood M, Fukasawa M, Gruber N, Johnson GC, Körtzinger A, Sabine C, Sloyan B, Stansfield K, Tanhua T. 2010a. Ship-based repeat hydrography: A strategy for a sustained global program. Proceedings of OceanObs'09: Sustained Ocean Observations and Information for Society (Vol. 2), 2009: ed. J Hall, DE Harrison, D Stammer, Venice, Italy, ESA Publication WPP-306, doi:10.5270/OceanObs09.cwp.42 
Hood EM, Sabine CL, Sloyan BM, Eds. 2010b. The GO-SHIP Repeat Hydrography

Manual: A Collection of Expert Reports and Guidelines. IOCCP Report Number 14, ICPO Publication Series Number 134. Available online at http://www.go-

\section{ship.org/HydroMan.html}

\section{Acknowledgements}

The authors acknowledge support from: Climate Observations Division of the U.S. NOAA Climate Program Office and NOAA Research; Joint Institute for the Study of the Atmosphere and Ocean (JISAO) under NOAA Cooperative Agreement

NA10OAR4320148; U.S. National Science Foundation [OCE- 0223869; OCE-0752970; OCE-0825163; OCE-1434000; OCE 0752972; OCE-0752980; OCE-1232962; OCE1155983; OCE-1436748]; U.S. CLIVAR Project Office; Global Environment and Marine Department, Japan Meteorological Agency; Australian Climate Change Science Program (Australian Department of Environment and CSIRO); U.K. Natural Environment Research Council; European Union’s FP7 grant agreement 264879 (CarboChange); Horizon 2020 grant agreement No 633211; ETH Zurich Switzerland. This is JISAO contribution number 2434 and NOAA/PMEL contribution number 4329.

\section{Sidebar}

The Atlantic Meridional Overturning Circulation (AMOC) transports warm upper ocean waters northward that are cooled in large heat loss regions of the North Atlantic and Nordic Seas. It returns southward as cold North Atlantic Deep Water. This results in a large northward heat transport through the full length of the Atlantic. The AMOC strength and heat transport are of significance to climate at decadal to millennial timescales. Climate models project an anthropogenic decrease in AMOC strength due to increasing stratification in the north (Carton et al. 2014). Bryden et al. (2005) reported decreasing AMOC strength since the 1950s using hydrographic sections at $24^{\circ}-26^{\circ} \mathrm{N}$ repeated over several decades, but seasonally biased to summer. Direct measurements of the AMOC since 2004 show large seasonal and interannual variability, but also a small decrease from 2004 to 2012 (Rayner et al. 2011; McCarthy et al. 2015), that is seen in an historical AMOC reconstruction from 1980 to 2005 based on hydrographic stations 
(Longworth et al. 2011). Rahmstorf et al. (2015) suggest that this recent decline is part of both decadal-scale variability and a trend going back to at least the 1930's, and likely as far back as the 1800's, based on paleo-reconstructions. Taken together, all suggest that indeed the AMOC is slightly slowing. 


\section{Literature cited}

Aoki S, Bindoff NL, Church JA. 2005. Interdecadal water mass changes in the Southern Ocean between $30^{\circ} \mathrm{E}$ and $160^{\circ} \mathrm{E}$. Geophys. Res. Lett., 32, L07607, doi:10.1029/2004GL022220

Bindoff, N. L., and T. J. McDougall, 2000: Decadal changes along an Indian Ocean section at $32^{\circ} \mathrm{S}$ and their interpretation. J. Phys. Oceanogr., 30, 1207-1222, doi: 10.1175/1520-0485(2000)030<1207:DCAAIO>2.0.CO;2.

Bindoff, N. L., et al., 2007: Observations: Oceanic climate change and sea level. Climate Change 2007: The Physical Science Basis. Contribution of Working Group I to the Fourth Assessment Report of the Intergovernmental Panel on Climate Change, S. Solomon, D. Qin, M. Manning, Z. Chen, M. Marquis, K. Averyt, M. Tignor, and H. L. Miller, Eds. Cambridge University Press, 385-432.

Boyer, T. P., S. Levitus, J. I. Antonov, R. A. Locarnini, and H. E. Garcia, 2005: Linear trends in salinity for the World Ocean, 1955-1998. Geophys. Res. Lett., 32, L01604, doi: 10.1029/2004GL021791.

Brown, P.J., D.C.E. Bakker, U. Schuster, and A.J. Watson, 2010. Anthropogenic carbon accumulation in the subtropical North Atlantic. J Geophys. Res. 115, C04016, doi: 10.1029/2008JC005043.

Bryden, H. L., H. R. Longworth, and S. A. Cunningham, 2005: Slowing of the Atlantic meridional overturning circulation at $25^{\circ} \mathrm{N}$. Nature, 438, 655-657, doi:10.1038/nature04385.

Bryden, H. L., E. L. McDonagh, and B. A. King, 2003. Changes in Ocean Water Mass Properties: Oscillations or Trends? Science, 27, 2086-2088.

doi:10.1126/science.1083980.

Bullister, J. L., 2014: Atmospheric CFC-11, CFC-12, CFC-113, CCl4, and SF 6 histories (1910-2014), http://cdiac.ornl.gov/oceans/new_atmCFC.html.

Bullister, J. L., D. P. Wisegarver, and F. A. Menzia., 2002: The solubility of sulfur hexafluoride in water and seawater. Deep-Sea Res. I, 49, 175-187, doi: 10.1016/S0967-0637(01)00051-6. 
Byrne, R. H., S. Mecking, R. A. Feely, and X. Liu, 2010: Direct observations of basinwide acidification of the North Pacific. Geophys. Res. Lett., 37, L02601, doi:10.1029/2009GL040999.

Carlson, C. A., H. W. Ducklow, and A. F. Michaels, 1994: Annual flux of dissolved organic carbon from the euphotic zone in the northwestern Sargasso Sea. Nature, 371, 405-408, doi:10.1038/371405a0.

Carlson, C.A., Hansell, D.A., 2015. DOM sources, sinks, reactivity and budgets, in: Hansell, D.A., Carlson, C.A. (Eds.), Biogeochemistry of marine dissolved organic matter 2nd Edition. Academic Press, New York, pp. 65-126.

Carlson, C. A., D. A. Hansell, N. B. Nelson, D. A. Siegel, W. M. Smethie, et al., 2010: Dissolved organic carbon export and subsequent remineralization in the mesopelagic and bathypelagic realms of the North Atlantic basin. Deep-Sea Res. II, 57, 1433-1445. doi:10.1016/j.dsr2.2010.02.013.

Carton, J.A., S. A. Cunningham, E. Frajka-Williams, Y.-O. Kwon, D. P. Marshall, and R. Msadek, 2014: The Atlantic Overturning Circulation: More Evidence of Variability and Links to Climate. Bull. Amer. Meteor. Soc., 95, ES163-ES166. doi: http://dx.doi.org/10.1175/BAMS-D-13-00234.1

Carton, J.A. and S. Hakkinen, 2011 Introduction to: Atlantic Meridional Overturning Circulation (AMOC). Deep-Sea Res. II, 58, 1741-1743. doi:10.1016/j.dsr2.2010.10.055.

Church, J. A., N. J. White, L. F. Konikow, C. M. Domingues, J. G. Cogley, E. Rignot, J. M. Gregory, M. R. van den Broeke, A. J. Monaghan, and I. Velicogna, 2011:

Revisiting the Earth's sea level and energy budgets from 1961 to 2008. Geophys. Res. Lett., 38, L18601, doi:10.1029/2001GL048794.

Copin-Montgut, G., and B. Avril, 1993: Vertical distribution and temporal variation of dissolved organic carbon in the North-Western Mediterranean Sea. Deep-Sea Res. I, 40, 1963-1972, doi:10.1016/0967-0637(93)90041-Z.

Curry, R. G., and M. S. McCartney, 2001: Ocean gyre circulation changes associated with the North Atlantic Oscillation. J. Phys. Oceanogr., 31, 3374-3400, doi: 10.1175/1520-0485(2001)0312.0.CO;2. 
Decloedt, T. and D.S. Luther, 2012. Spatially heterogeneous diapycnal mixing in the abyssal ocean: A comparison of two parameterizations to observations. Journal of Geophysical Research, 117, doi: 10.1029/2012JC008304. issn: 0148-0227.

Deutsch, C., S. Emerson, and L. Thompson, 2005: Fingerprints of climate change in North Pacific oxygen. Geophys. Res. Lett., 32, L16604, doi: 10.1029/2005GL023190.

Di Lorenzo, E., J. Fiechter, N. Schneider, A. Bracco, A.J. Miller, et al., 2009. Nutrient and salinity decadal variations in the central and eastern North Pacific. Geophysical Research Letters 36, L14601, doi:10.1029/2009GL038261.

Doney S.C., 2010. The growing human footprint on coastal and open-ocean biogeochemistry. Science 328: 1512-1516, doi:10.1126/science.1185198.

Doney, S.C. and W.J. Jenkins, 1994. Ventilation of the deep western boundary current and the abyssal western North Atlantic: estimates from tritium and 3He distributions. J. Phys. Oceanogr., 24, 638-659.

Doney, S. C., W. J. Jenkins, and J. L. Bullister, 1997: A comparison of ocean tracer dating techniques on a meridional section in the eastern North Atlantic. Deep-Sea Res. I, 44, 603-626, doi: 10.1016/ S0967-0637(96)00105-7.

Durack, P. J., and S. E. Wijffels, 2010: Fifty-year trends in global ocean salinities and their relationship to broad-scale warming. J. Climate, 23, 4342-4362, doi:10.1175/2010jcli3377.1.

Durack, P. J., S. E. Wijffels, and R. J. Matear, 2012: Ocean salinities reveal strong global water cycle intensification during 1950 to 2000. Science, 336, 455-458, doi:10.1126/science.1212222.

Dutay, J.-C., J.L. Bullister, S.C. Doney, J.C. Orr, R. Najjar, et al. 2002: Evaluation of ocean model ventilation with CFC-11: comparison of 13 global ocean models. Ocean Modelling, 4, 89-120.

Emerson, S., S. Mecking, and J. Abell, 2001: The biological pump in the subtropical North Pacific Ocean: Nutrient sources, Redfield ratios, and recent changes. Global Biogeochem. Cycles, 15, 535-554, doi: 10.1029/2000GB001320.

Emerson, S., Y. W. Watanabe, T. Ono, and S. Mecking, 2004: Temporal trends in apparent oxygen utilization in the upper pycnocline of the North Pacific: 1980-2000. J. Oceanogr., 60, 139-147, doi:10.1023/B:JOCE.0000038323.62130.a0. 
Feely, R. A., C. L. Sabine, K. Lee, W. Berelson, J. Kleypas, V. J. Fabry, and F. J. Millero, 2004: Impact of anthropogenic $\mathrm{CO}_{2}$ on the $\mathrm{CaCO}_{3}$ system in the oceans. Science, 305, 362-366, doi:10.1126/ science.1097329.

Feely, R. A., S. C. Doney, and S. R. Cooley, 2009: Ocean acidification: Present conditions and future changes in a high- $\mathrm{CO}_{2}$ world. Oceanography, 22, 36-47, doi:10.5670/oceanog.2009.95.

Fine, R. A., 2011: Observations of CFCs and $\mathrm{SF}_{6}$ as ocean tracers. Annual Rev. Mar. Sci., 3, 173-195.

Fine, R. A., S. Peacock, M. E. Maltrud, and F. O. Bryan, 2014: A new look at ocean ventilation timescales. Abstract, 2014 Ocean Sciences Meeting, Honolulu, Hawaii.

Frajka-Williams, E., S. A. Cunningham, H. Bryden, and B. A. King, 2011: Variability of Antarctic Bottom Water at $24.5^{\circ} \mathrm{N}$ in the Atlantic. J. Geophys. Res., 116, C11026, doi:10.1029/2011JC007168.

Friis, K., A. Körtzinger, J. Pätsch, and D. W. R. Wallace, 2005: On the temporal increase of anthropogenic $\mathrm{CO}_{2}$ in the subpolar North Atlantic. Deep-Sea Res. I, 52, 681-698, doi: 10.1016/j.dsr.2004.11.017.

Frölicher, T. L., F. Joos, G. K. Plattner, M. Steinacher, and S. C. Doney, 2009: Natural variability and anthropogenic trends in oceanic oxygen in a coupled carbon cycleclimate model ensemble. Global Biogeochem. Cycles, 23, GB1003, doi:10.1029/2008GB003316.

Frölicher, T. L., M. Winton, and J. L. Sarmiento, 2014: Continued global warming after CO2 emissions stoppage. Nature Climate Change, 4, 40-44, doi:10.1038/NCLIMATE2060

Fukasawa M, Freeland H, Perkin R, Watanabe T, Uchida H, Nishina A. 2004. Bottom water warming in the North Pacific Ocean. Nature, 427(6977), 825-827

Ganachaud, A., and C. Wunsch, 2000: Improved estimates of global ocean circulation, heat transport and mixing from hydrographic data. Nature, 408, 453-456, doi:10.1038/35044048.

Gloor, M., N. Gruber, J. L. Sarmiento, C. L. Sabine, R. A. Feely, and C. Rödenbeck, 2003: A first estimate of present and preindustrial air-sea $\mathrm{CO}_{2}$ flux patterns based on ocean 
interior carbon measurements and models. Geophys. Res. Lett., 30, 1010, doi:10.1029/2002GL015594.

Goldberg, S., C. Carlson, M. Brzezinski, N. Nelson, and D. Siegel, 2011: Systematic removal of neutral sugars within dissolved organic matter across ocean basins. Geophys. Res. Lett., 38, doi:10.1029/2011GL048620.

Graven, H.D., N. Gruber, R. Key, S. Khatiwala, and X. Giraud, 2012: Changing controls on oceanic radiocarbon: New insights on shallow-to-deep ocean exchange and anthropogenic CO2 uptake. J. Geophys. Res., 117, C10005, doi:10.1029/2012JC008074.

Gregg, M. C., 1989: Scaling turbulent dissipation in the thermocline. J. Geophys. Res., 94, 9686-9698, doi:10.1029/JC094iC07p09686.

Gregg, M. C., T. B. Sanford, and D. P. Winkel, 2003: Reduced mixing from the breaking of internal waves in equatorial waters. Nature, 422, 513-515.

Gruber, N., J. L. Sarmiento, and T. F. Stocker, 1996: An improved method for detecting anthropogenic $\mathrm{CO}_{2}$ in the oceans. Global Biogeochem. Cycles, 10, 809-837, doi:10.1029/96GB01608.

Gruber, N., M. Gloor, S. E. Mikaloff Fletcher, S. C. Doney, S. Dutkiewicz, et al., 2009: Oceanic sources, sinks, and transport of atmospheric $\mathrm{CO}_{2}$. Global Biogeochem. Cycles, 23, GB1005, doi: 10.1029/2008GB003349.

Hakkinen, S., and P. B. Rhines, 2004: Decline of subpolar North Atlantic circulation during the 1990s. Science, 302, 555-55, doi: 10.1126/science.1094917.

Hakkinen, S., H. Hatun, and P. B. Rhines, 2008: Satellite evidence of change in the northern gyre. Arctic-Subarctic Ocean Fluxes: Defining the Role of the Northern Seas in Climate, B. Dickson, J. Meincke, and P. Rhines, Eds., Springer, 551-567.

Hall, T. M., T. W. N. Haine, M. Holzer, D. A. LeBel, F. Terenzi, and D. W. Waugh, 2007: Ventilation rates estimated from tracers in the presence of mixing. J. Phys. Oceanogr., 37, 2599-2611, doi:10.1175/2006JPO3471.1.

Hansell, D. A., 2013: Recalcitrant dissolved organic carbon fractions. Annu. Rev. Mar. Sci., 5, 421-445, doi:10.1146/annurev-marine-120710-100757. 
Hansell, D. A., C. A. Carlson, D. J. Repeta, and R. Schlitzer, 2009. Dissolved organic matter in the ocean: A controversy stimulates new insights. Oceanography, 22, 202211, doi:10.5670/ oceanog.2009.109.

Hansell, D. A., C. A. Carlson, and R. Schlitzer, 2012: Net removal of major marine dissolved organic carbon fractions in the subsurface ocean. Global Biogeochem. Cycles, 26, doi:10.1029/2011GB004069.

Hansell, D.A., D.B. Olson, F. Dentener, and L.M. Zamora. 2007. Assessment of excess nitrate development in the subtropical North Atlantic. Marine Chemistry 106(3): 562-579.

Hartin, C. A., R. A. Fine, I. Kamenkovich, and B. M. Sloyan, 2014: Comparison of Subantarctic Mode Water and Antarctic Intermediate Water formation rates in the South Pacific between NCAR- CCSM4 and observations. Geophys. Res. Lett., 41, 519-526, doi:10.1002/2013GL058728.

Helm, K. P., N. L. Bindoff, and J. A. Church, 2010: Changes in the global hydrologicalcycle inferred from ocean salinity. Geophys. Res. Lett., 37. doi:10.1029/2010gl044222.

Helm, K. P., N. L. Bindoff, and J. A. Church, 2011: Observed decreases in oxygen content of the global ocean. Geophys. Res. Lett., 38, L23602, doi:10.1029/2011GL049513.

Henyey, F. S., J. A. Wright, and S. M. Flatt $\square$ e (1986), Energy and action flow through the internal wave field: An eikonal approach, J. Geophys. Res., 91, 8487-8495.

Hernández-Guerra, A., T. M. Joyce, E. Fraile-Nuez, and P. Vélez-Belchi, 2010: Using Argo data to investigate the meridional overturning circulation in the North Atlantic. Deep-Sea Res. I, 57, 29-36, doi: 10.1016/j.dsr.2009.10.003.

Hernández-Guerra, A.,J. L. Pelegri, E. Fraile-Nuez, V. Benitez-Barrios, M. Emilianov, M. Dl. Perez-Hernandez, P. Velez-Belchi, 2014. Meridional overturning transports at 7.5N and 24.5N in the Atlantic Ocean during 1992-39 and 2010-11. Prog. in Oceanogr.,128, 98-114.

Holzer, M., F.W. Primeau, W.M. Smethie, Jr., S. Khatiwala, T. Hall, 2010. Where and how long ago was water in the western North Atlantic ventilated? Maximum-entropy 
inversions of bottle data from WOCE line A20. JGR Oceans, 115, C07005, doi:10.1029/2009JC005750.

Huhn, O., M. Rhein, M. Hoppema, and S. van Heuven, 2013: Decline of deep and bottom water ventilation and slowing down of anthropogenic carbon storage in the Weddell Sea, 1984-2011. Deep Sea Res. I, 76, 66-84, doi:10.1016/j.dsr.2013.01.005.

Huussen, T. N., A. C. Naveira-Garabato, H. L. Bryden, and E. L. McDonagh, 2012: Is the deep Indian Ocean MOC sustained by breaking internal waves? J. Geophys. Res., 117, C08024, doi:10.1029/2012JC008236.

Jacobs, S. S., and C. F. Giulivi. 2010. Large multidecadal salinity trends near the Pacific Antarctic continental margin. J. Climate 23, 4508-4524, doi:10.1175/2010JCLI3284.1.

Jenkins, W.J., 1977. Tritium-helium dating in the Sargasso Sea: a measurement of oxygen utilization rates. Science, 196, 291-292.

Jenkins, W.J., 1998. Studying thermocline ventilation and circulation using tritium and ${ }^{3}$ He. Journal of Geophysical Research, 103, 15817-15831.

Johnson, G. C., 2008: Quantifying Antarctic Bottom Water and North Atlantic deep water volumes. J. Geophys. Res., 113, C05027, doi:10.1029/2007JC004477.

Johnson, G. C., and N. Gruber, 2007: Decadal water mass variations along $20^{\circ} \mathrm{W}$ in the northeastern Atlantic Ocean. Prog. Oceanogr., 73, 277-295, doi:10.1016/j.pocean.2006.03.022.

Johnson, G. C., K. E. McTaggart, and R. Wanninkhof, 2014: Antarctic Bottom Water temperature changes in the western South Atlantic from 1989 to 2014. J. Geophys. Res., 119, 8567-8577, doi:10.1002/2014JC010367.

Johnson, G. C., S. G. Purkey, and J. M. Toole, 2008: Reduced Antarctic meridional overturning circulation reaches the North Atlantic Ocean. Geophys. Res. Lett., 35, L22601, doi:10.1029/2008GL035619.

Kamykowski, D., S.J. Zentara, 2005. Changes in world ocean nitrate availability through the 20th century. Deep-Sea Res. I, 52: 1719-1744, doi:10.1016/j.dsr.2005.04.007.

Katsumata, K., and S. Masuda, 2013: Variability in Southern Hemisphere Ocean Circulation from the 1980s to the 2000s, J.Phys.Oceanogr., 43, 1981-2007, doi:10.1175/JPO-D-12-0209.1. 
Katsumata, K., H. Nakano, and Y. Kumamoto, 2015: Dissolved oxygen change and freshening of Antarctic Bottom water along $62^{\circ} \mathrm{S}$ in the Australian-Antarctic Basin between 1995/1996 and 2012/2013, Deep-Sea Res. II, 114, 27-38, ISSN 0967-0645, doi:10.1016/j.dsr2.2014.05.016.

Keeling, R. F., A. Körtzinger, and N. Gruber, 2010: Ocean deoxygenation in a warming world. Annu. Rev. Mar. Sci., 2, 199-229, doi:10.1146/annurev.marine.010908.163855.

Keeling, R. F., and A. C. Manning, 2014: Studies of recent changes in atmospheric $\mathrm{O}_{2}$ content. Treatise on Geochemistry, 2nd ed., Vol. 5, H. D. Holland, and K. K. Turekian, Eds., Elsevier, 385-404.

Key, R. M., A. Kozyr, C. L. Sabine, K. Lee, R. Wanninkhof, et al., 2004: A global ocean carbon climatology: Results from Global Data Analysis Project (GLODAP). Global Biogeochem. Cycles, 19, GB4031, doi:10.1029/2004GB002247.

Khatiwala, S., F. Primeau, and T. Hall, 2009: Reconstruction of the history of anthropogenic $\mathrm{CO}_{2}$ concentrations in the ocean. Nature, 462, 346-349, doi:10.1038/nature08526.

Khatiwala, S., T. Tanhua, S. Mikaloff Fletcher, M. Gerber, S. C. Doney, et al., 2013: Global ocean storage of anthropogenic carbon. Biogeosciences, 10, 2169-2191, doi:10.5194/bgd-9-8931-2012.

Kieke, D., M. Rhein, L. Stramma, W. M. Smethie, D. A. LeBel, and W. Zenk, 2006: Changes in the CFC inventories and formation rates of Upper Labrador Sea Water, 1997-2001. J. Phys. Oceanogr., 36, 64-86, doi:10.1029/2066GL028959.

Kieke, D., M. Rhein, L. Stramma, W. M. Smethie, J. L. Bullister, and D. A. LeBel, 2007: Changes in the pool of Labrador Sea Water in the subpolar North Atlantic. Geophys. Res. Lett., 34, doi:10.1029/2006GL028959.

Kim, I.N., K. Lee, N. Gruber, D.M. Karl, J.L. Bullister, et al., 2014. Increasing anthropogenic nitrogen in the North Pacific Ocean. Science 346(6213): 11021106.

Kobayashi, T., K. Mizuno, and T. Suga, 2012: Long-term variations of surface and intermediate waters in the southern Indian Ocean along $32^{\circ} \mathrm{S}$. J. Oceanography, 68, 243-265, doi:10.1007/s10872-011-0093-5. 
Körtzinger, A., Rhein, M., Mintrop, L., 1999. Anthropogenic CO2 and CFCs in the North Atlantic Ocean- A comparison of man-made tracers. Geophys. Res. Let. 26, 20652068.

Kouketsu, S., T. Doi, T. Kawano, S. Masuda N. Sugiura, Y. Sasaki, T. Toyoda, H. Igarashi, Y. Kawai, K. Katsumata, H. Uchida, M. Fukasawa, and T. Awaji, 2011: Deep ocean heat content changes estimated from observation and reanalysis product and their influence on sea level change. J. Geophys. Res., 116, C03012, doi:10.1029/2010JC006464.

Kouketsu, S., M. Fukasawa, I. Kaneko, T. Kawano, H. Uchida, T. Doi, M. Aoyama, and K. Murakami, 2009: Changes in water properties and transports along $24^{\circ} \mathrm{N}$ in the North Pacific between 1985 and 2005. J. Geophys. Res., 114, C01008, doi:10.1029/2008JC004778.

Kouketsu, S., M. Fukasawa, D. Sasano, Y. Kumamoto, T. Kawano, H. Uchida, and T. Doi (2010), Changes in water properties around North Pacific intermediate water between the 1980s, 1990s and 2000s, Deep Sea Res., Part II, 57, 1177-1187, doi:10.1016/j.dsr2.2009.12.007.

Kouketsu, S., and A. M. Murata (2014), Detecting decadal scale increases in anthropogenic $\mathrm{CO}_{2}$ in the ocean, Geophys. Res. Lett., 41, 4594-4600, doi:10.1002/2014GL060516.

Kunze, E., E. Firing, J. M. Hummon, T. K. Chereskin, and A. M. Thurnherr, 2006: Global abyssal mixing from lowered ADCP shear and CTD strain profiles. J. Phys. Oceanogr. 36: 1553-1576, doi:10.1175/ JPO2926.1.

LaCasce JH, Ferrari R, Marshall J, Tulloch R, Balwada D, Speer K. 2014. Float-Derived Isopycnal Diffusivities in the DIMES Experiment. J. Phys. Oceanogr. 44(2): 764-780, doi:10.1175/JPO-D-13-0175.1

Landschützer, P., N. Gruber, D. C. E. Bakker, and U. Schuster, 2014. Recent variability of the global ocean carbon sink, Global Biogeochem. Cycles, 28, 927-949, doi:10.1002/2014GB004853

LeBel, D. A., W. M. Smethie, Jr., M. Rhein, D. Kieke, R. A. Fine, et al.21 2008: The formation rate of North Atlantic Deep Water and Eighteen Degree Water calculated 
from CFC-11 inventories observed during WOCE. Deep-Sea Res. I, 55, 891-910, doi:10.1016/j.dsr.2008.03.009.

Levine, N.M., S.C. Doney, R. Wanninkhof, K. Lindsay, and I. Fung, 2008: Impact of ocean carbon system variability on the detection of temporal increases in anthropogenic CO2, J. Geophys. Res. Oceans, 113, C03019, doi:10.1029/2007JC004153.

Levine, N. M., S. C. Doney, I. Lima, R. Wanninkhof, N. R. Bates, and R. A. Feely (2011), The impact of the North Atlantic Oscillation on the uptake and accumulation of anthropogenic $\mathrm{CO}_{2}$ by North Atlantic Ocean mode waters, Global Biogeochem. Cycles, 25, GB3022, doi:10.1029/2010GB003892.

Loeb, N. G., J. M. Lyman, G. C. Johnson, D. R. Doelling, T. Wong, R. P. Allan, B. J. Soden, and G. L. Stephens, 2012: Observed changes in top-of-the-atmosphere radiation and upper-ocean heating consistent within uncertainty. Nature Geosci., 5, 110-113, doi:10.1038/ngeo1375.

Long, M.C., K. Lindsay, S. Peacock, J.K. Moore, and S.C. Doney, 2013: Twentieth-century ocean carbon uptake and storage in CESM1(BGC), J. Climate, 26(18), 6775-6800, doi: 10.1175/JCLI-D-12-00184.1

Longworth, H.R., H.L. Bryden, and M.O. Baringer, 2011. Historical variability in Atlantic meridional baroclinic transport at $26.5^{\circ} \mathrm{N}$ from boundary dynamic height observations. Deep-Sea Res. II, 58, 1754-1767, doi:10.1016/j.dsr2.2010.10.057

Lozier, M. S., 2010: Deconstructing the conveyor belt. Science, 328, 1507-1511, doi:10.1126/science.1189250.

Lumpkin, R., and K. Speer, 2007: Global ocean meridional overturning. J. Phys. Oceanogr., 37, 2550-2562, doi:10.1175/JPO3130.1.

Macdonald, A. M. and M. O. Baringer. 2013. Ocean heat transport, Chapter 29. In Ocean Circulation and Climate, A $21^{\text {st }}$ Cenury Perspective, eds: J. Church, J. Gould, S. Griffies and G. Siedler. In International Geophysics Volume 103, Academic Press, Elsevier, Amsterdam, 759-784. 
Macdonald, A. M., S. Mecking, P. E. Robbins, J. M. Toole, G. C. Johnson, et al., 2009:

The WOCE-Era 3-D Pacific Ocean circulation and heat budget. Prog. Oceanogr., 82, 281-325, doi:10.1016/j.pocean.2009.08.002

Masuda, S., T. Awaji, N. Sugiura, J. P. Matthews, T. Toyoda, Y. Kawai, et al., 2010:

Simulated rapid warming of abyssal North Pacific water. Science, 329, 319-322, doi:10.1126/science.1188703.

Matear, R. J., and A. C. Hirst, 2003: Long-term changes in dissolved oxygen concentrations in the ocean caused by protracted global warming. Global Biogeochem. Cycles, 17, 1125, doi:10.1029/2002GB001997.

Matsumoto, K., J.L. Sarmiento, R.M. Key, J.L. Bullister, K. Caldeira, et al., 2004:

Evaluation of ocean carbon cycle models with data-based metrics, Geophys. Res. Lett., 31, L07303, doi:10.1029/2003GL018970.

Mauritzen, C., A. Melsom, and R. T. Sutton, 2012: Importance of density-compensated temperature change for deep North Atlantic Ocean heat uptake. Nature Geosci., 5, 905_910, doi:10.1038/ngeo1639.

McCarthy, G., D.A. Smeed, W. E. Johns, E. Frajka-Williams, B.I. Moat, et al., 2015: Measuring the Atlantic meridional overturning circulation at $26^{\circ} \mathrm{N}$. Prog. in Oceanogr., 130,91-111.

McDonagh, E. L., H. L. Bryden, B. A. King, R. J. Sanders, S. A. Cunningham, and R. Marsh, 2005: Decadal changes in the South Indian Ocean thermocline. J. Climate, 18, 1575-1590, doi:10.1175/ JCLI3350.1.

McDonagh, E. L., H. L. Bryden, B. A. King, and R. J. Sanders, 2008: The circulation of the Indian Ocean at $32^{\circ}$ S. Prog. Oceanogr., 79, 20-36, doi:10.1016/j.pocean.2008.07.001.

Mecking, S., G. C. Johnson, J. L. Bullister, and A. M. Macdonald, 2012: Decadal changes in oxygen and temperature-salinity relations along $32^{\circ} \mathrm{S}$ in the Indian Ocean through 2009. Abstract 2012 Ocean Sciences Meeting. Salt Lake City, Utah.

Mecking, S., C. Langdon, R. A. Feely, C. L. Sabine, C. A. Deutsch, and D.-H. Min, 2008: Climate variability in the North Pacific thermocline diagnosed from oxygen measurements: An update based on the US CLIVAR/ $/ \mathrm{CO}_{2}$ Repeat Hydrography cruises. Global Biogeochem. Cycles, 22, GB3015, doi:10.1029/2007GB003101. 
Mecking, S., M. J. Warner, and J. L. Bullister. 2006. Temporal changes in PCFC ages and AOU along two hydrographic sections in the eastern subtropical North Pacific. DeepSea Res. I, 53, 169-187, doi:10.1016/j.dsr.2005.06.018.

Melet, A., R. Hallberg, S. Legg, and K. Polzin, 2013: Sensitivity of the Pacific Ocean state to the vertical distribution of internal-tide driven mixing. J. Phys. Oceanogr., 43, 602-615, doi:10.1175/ JPO-D-12-055.1.

Munk W. 1966. Abyssal recipes. Deep-Sea Res. 13, 707-730.

Murata, A., Y. Kumamoto, K. Sasaki, S. Watanabe, Fukasawa, M., 2008. Decadal increases of anthropogenic CO in the subtropical South Atlantic Ocean along $30^{\circ} \mathrm{S}$. J Geophys. Res. 113, doi:10.1029/2007JC004424.

Murata, A., Y. Kumamoto, S. Watanabe, and M. Fukasawa, 2007: Decadal increases of anthropogenic $\mathrm{CO}_{2}$ in the South Pacific subtropical ocean along $32^{\circ}$ S. J. Geophys. Res., 112, C05033, doi:10.1029/2005JC003405.

Murata, A., Y. Kumamoto, K. Sasaki, S. Watanabe, and M. Fukasawa, 2010: Decadal increases in anthropogenic $\mathrm{CO}_{2}$ along $20^{\circ} \mathrm{S}$ in the South Indian Ocean. J. Geophys. Res., 115, C12055, doi:10.1029/2010JC006250.

Naegler, T., P. Ciais, K.B. Rodgers, and I. Levin, 2006: Excess radiocarbon constraints on air-sea gas exchange and the uptake of $\mathrm{CO} 2$ by the oceans. Geophys. Res. Lett. , 33, L11802, doi:10.1029/2005GL025408.

Nakano, T., T. Kitamura, S. Sugimoto, T. Suga, and M. Kamachi, 2015. Long- term variations of North Pacific Tropical Water along the $137^{\circ} \mathrm{E}$ repeat hydrographic section. J. Oceanogr., doi: 10.1007/s10872-015-0279-3.

Naveira Garabato, A. C., K. L. Polzin, B. A. King, K. J. Heywood, and M. Visbeck, 2004: Widespread intense turbulent mixing in the Southern Ocean. Science, 303, 210 213, doi:10.1126/ science.1090929.

Olsen, A., R. M. Key, S. K. Lauvset, X. Lin, T. Tanhua, et al., 2014: Global Ocean Data Analysis Project Version 2 (GLODAPv2), 2014 Ocean Sciences Meeting, Honolulu, Hawaii.

Ono, T., T. Midorikawa, Y. Watanabe, K. Tadokoro, and T. Saino (2001), Temporal increases of phosphate and apparent oxygen utilization in the subsurface waters of western subarctic Pacific from 1968 to 1998, Geophys. Res. Lett., 28 (17), 3285-3288. 
Orr, J. C., V. J. Fabry, O. Aumont, L. Bopp, S. C. Doney, et al., 2005: Anthropogenic ocean acidification over the twenty-first century and its impact on calcifying organisms. Nature, 437, 681-686, doi:10.1038/nature04095.

Orsi, A. H., W. M. Smethie, Jr., and J. L. Bullister, 2002: On the total input of Antarctic waters to the deep ocean: A preliminary estimate from chlorofluorocarbon measurements. J. Geophys. Res., 107, 31-1-31-14., doi:10.1029/2001JC000976.

Palmer, M. D., H. L. Bryden, J. Hirschi, and J. Marotzke, 2004: Observed changes in the South Indian Ocean gyre circulation, 1987-2002. Geophys. Res. Lett., 31, L15303, doi:10.1029/2004GL020506.

Pardo, P. C., F. F. Pérez, S. Khatiwala, and A. F. Ríos, 2014: Anthropogenic $\mathrm{CO}_{2}$ estimates in the Southern Ocean: Storage partitioning in the different water masses. Prog. Oceanogr., 120, 230-242, doi: 10.1016/j.pocean.2013.09.005.

Peacock, S., M. Maltrud, and R. Bleck, 2005: Putting models to the data test: A case study using Indian Ocean CFC-11 data. Ocean Model., 9, 1-22, doi:10.1016/j.ocemod.2004.02.004.

Pérez, F. F., M. Vázquez-Rodríguez, H. Mercier, A. Velo, P. Lherminier, and A. F. Ríos, 2010: Trends of anthropogenic $\mathrm{CO}_{2}$ storage in North Atlantic water masses. Biogeosciences, 7, 1789-1807, doi:10.5194/bg-7-1789-2010.

Pérez, F. F., Mercier, H., Vázquez-Rodríguez, M., Lherminier, P., Velo, A., et al., 2013: Atlantic Ocean $\mathrm{CO}_{2}$ uptake reduced by weakening of the meridional overturning circulation, Nat. Geosci., 6, 146-152, 10.1038/ngeo1680.

Polzin, K. L., J. M. Toole, and R. W. Schmitt, 1995: Finescale parameterizations of turbulent dissipation. J. Phys. Oceanogr., 25, 306-328, doi:10.1175/15200485(1995)025<0306:FPOTD>2.0.CO;2.

Polzin, K. L., A. C. N. Garabato, T. N. Huussen, B. M. Sloyan, and S. Waterman, 2014: Finescale parameterizations of turbulent dissipation. J. Geophys. Res. Oceans, 119, doi:10.1002/2013JC008979.

Purkey, S. G., and G. C. Johnson, 2010: Warming of global abyssal and deep Southern Ocean waters between the 1990s and 2000s: Contributions to global heat and sea level rise budgets. J. Climate, 23, 6336-6351, doi:10.1175/2010JCLI3682.1. 
Purkey, S. G., and G. C. Johnson, 2012: Global contraction of Antarctic Bottom Water between the 1980s and 2000s. J. Climate, 25, 5830-5844, doi:10.1175/JCLI-D-1100612.1.

Purkey, S. G., and G. C. Johnson, 2013: Antarctic Bottom Water warming and freshening: Contributions to sea level rise, ocean freshwater budgets, and global heat gain. $J$. Climate, 26, doi:10.1175/JCLI-D-12-00834.1.

Rahmstorf, S., J. E. Box, G. Feulner, M. E. Mann, A. Robinson, S. Rutherford, and E. J. Schaffernicht, 2015: Exceptional twentieth-century slowdown in Atlantic Ocean overturning circulation. Nature Climate Change, doi: 10.1038/NCLIMATE2554.

Rayner, D., J. M.M. Hirschi, T. Kanzow, W. E. Johns, P. G. Wright, et al. 2011: Monitoring the Atlantic meridional overturning circulation. Deep Sea Res., Part II, 58(17-18), 1744-1753. doi:10.1016/j.dsr2.2010.10.056

Rhein, M., J. Fischer, W. M. Smethie, Jr., D. Smythe-Wright, D. H. Min, C. Mertens, et al. 2002: Labrador Sea Water: Pathways, CFC-inventory and formation rates. J. Phys. Oceanogr., 32, 648-665, doi: 10.1175/1520-0485(2002)032<0648:LSWPCI>2.0.CO;2.

Rhein, M., D. H. Kieke, S. Huttl-Kabus, A. Roessler, C. Mertens, et al. 2011. Deep water formation, the subpolar gyre, and the meridional overturning circulation in the subpolar North Atlantic. Deep-Sea Res. II, 58, 1819-1832, doi: 10.1016/j. dsr2.2010.10.061.

Rhein, M., S. R. Rintoul, S. Aoki, E. Campos, D. Chambers, et al., 2013: Observations: Ocean. Climate Change 2013: The Physical Science Basis. Contribution of Working Group I to the Fifth Assessment Report of the Intergovernmental Panel on Climate Change, T. F. Stocker, D. Qin, G.-K. Plattner, M. Tignor, S. K. Allen, J. Boschung, A. Nauels, Y. Xia, V. Bex, and P. M. Midgley, Eds., Cambridge University Press, 255310.

Rignot, E., J. L. Bamber, M. R. van Den Broeke, C. Davis, Y. Li, W. Jan Van De Berg, and E. van Meijgaard, 2008: Recent Antarctic ice mass loss from radar interferometry and regional climate modeling. Nat. Geosci., 1, 106-110, doi:10.1038/ngeo102.

Roemmich, D., J. Church, J. Gilson, D. Monselesan, P. Sutton, and S. Wijffels, 2015: Unabated planetary warming and its ocean structure since 2006. Nature Climate Change, 5, 240-245, doi:10.1038/nclimate2513. 
Roemmich. D., J. Gilson, R. Davis, P. Sutton, S. Wijffels, and S. Riser, 2007: Decadal spinup of the South Pacific subtropical gyre. J. Phys. Oceanogr., 37, 162-173, doi:10.1175/JPO3004.1.

Roemmich, D., and C. Wunsch, 1984: Apparent changes in the climate state of the deep North Atlantic Ocean. Nature, 307, 447-450, doi:10.1038/307447a0.

Sabine, C. L., R. A. Feely, N. Gruber, R. M. Key, K. Lee, et al., 2004: The oceanic sink for anthropogenic $\mathrm{CO}_{2}$. Science, 305, 367-371, doi:10.1126/science.1097403.

Sabine, C. L., R. A. Feely, F. J. Millero, A. G. Dickson, C. Langdon, et al., 2008: Decadal changes in Pacific carbon. J. Geophys. Res., 113, C07021, doi:10.1029/2007JC004577.

Sabine, C. L., and T. Tanhua, 2010: Estimation of anthropogenic $\mathrm{CO}_{2}$ inventories in the ocean. Annu. Rev. Mar. Sci., 2, 175-198, doi:10.1146/annurev-marine-120308080947.

Sarmiento, J. L., N. Gruber, M. A. Brzezinski, and J. P. Dunne, 2004: High-latitude controls of thermocline nutrients and low latitude biological productivity. Nature, 427, 56-60, doi:10.1038/ nature02127.

Sasano, D., Y. Takatani, N. Kosugi, T. Nakano, T. Midorikawa, and M. Ishii, Multidecadal trends of oxygen and their controlling factors in the western North Pacific, Global Biogeochem. Cycles, revised.

Sheen, K. L., J. A. Brearley, A. C. Naveira Garabato, D. A. Smeed, S. Waterman, et al. 2013. Rates and mechanisms of turbulent dissipation and mixing in the Southern Ocean: Results from the Diapycnal and Isopycnal Mixing Experiment in the Southern Ocean (DIMES). J. Geophys. Res., 118, 2774-2779, doi:10.1002/jgrc.20217.

Sloyan, B. M., 2005: Spatial variability of mixing in the Southern Ocean. Geophys. Res. Lett., 32, L18603, doi:10.1029/2005GL023568.

Sloyan, B. M. and S. R. Rintoul, 2001: The Southern Ocean limb of the global deep overturning circulation. J. Phys. Oceanogr., 31, 143-173.

Sloyan, B. M., S. E. Wijffels, B. Tilbrook, K. Katsumata, A. Murata, and A. M. Macdonald, 2013: Deep ocean changes near the western boundary of the South Pacific Ocean. J. Phys. Oceanogr., 43, 2132-2141, doi:10.1175/JPO-D-12-0182.1. 
Smethie, W. M., and R. A Fine, 2001: Rates of North Atlantic Deep Water formation calculated from chlorofluorocarbon inventories. Deep Sea Res. I, 48, 189-215, doi:10.1016/S0967-0637(00)00048-0.

Smethie, W. M., D. A. LeBel, R. A. Fine, M. Rhein, and D. Kieke. 2007: Strength and variability of the deep limb of the North Atlantic meridional overturning circulation from chlorofluorocarbon inventories. Past and Future Changes of the Ocean's Meridional Overturning Circulation: Mechanisms and Impacts, A. Schmittner, J. Chiang, and S. Hemming, Eds., AGU Geophysical Monograph Series, 173, 119-130.

Sonnerup, R. E., S. Mecking, and J. L. Bullister, 2013: Transit time distributions and oxygen utilization rates in the Northeast Pacific Ocean from chlorofluorocarbons and sulfur hexafluoride. Deep-Sea Res. I, 72, 61-71, doi:10.1016/j.dsr.2012.10.013.

Sonnerup, R. E., S. Mecking, J. L. Bullister, and M. J. Warner, 2015: Transit time distributions and oxygen utilization rates from chlorofluorocarbons and sulfur hexafluoride in the Southeast Pacific Ocean. J. Geophys. Res., doi:10.1002/2015JC010781, in press.

Stanley, R.H.R., Doney, S.C., Jenkins, W.J., Lott, D.E.I., 2012. Apparent oxygen utilization rates calculated from tritium and helium-3 profiles at the Bermuda Atlantic Time-series Study site. Biogeosciences, 9, 1969-1983.

Stendardo, I., and N. Gruber. 2012. Oxygen trends over five decades in the North Atlantic, J. Geophys. Res., 117, C11004, doi:10.1029/2012JC007909.

Stramma, L., S. Schmidtko, L. A. Levin, and G. C. Johnson, 2010: Ocean oxygen minima expansions and their biological impacts. Deep-Sea Res. I, 57, 587-595, doi:10.1016/j.dsr.2010.01.005.

Stramma, L., A. Oschlies, and S. Schmidtko, 2012: Mismatch between observed and modeled trends in dissolved upper-ocean oxygen over the last 50 yr. Biogeosciences, 9, 4045-4057, doi:10.5194/bg-9-4045-2012.

Sweeney, C., E. Gloor, A. J. Jacobson, R. M. Key, G. McKinley, J. L. Sarmiento and R. Wanninkhof, 2007. Constraining global air-sea exchange for CO2 with recent bomb 14C measurements, Global Biogeochem. Cycles, 21, GB2015, doi:10.1029/2006BG002784. 
Swift, J. H., and A. H. Orsi, 2012: Sixty-four days of hydrography and storms: RVIB Nathaniel B. Palmer's 2011 S04P Cruise. Oceanography, 25, 54-55, doi:10.5670/oceanog.2012.74.

Takahashi T, Sutherland SC, Wanninkhof R, Sweeney C, Feely R, et al., 2009.

Climatological mean and decadal change in surface ocean $\mathrm{pCO}_{2}$, and net sea- air $\mathrm{CO}_{2}$ flux over the global oceans. Deep-Sea Res. I, 56, 2075-2076, doi:10.1016/j.dsr2.2008.12.009.

Takatani, Y., A. Kojima, Y. Iida, T. Nakano, M. Ishii, et al., 2014: Ocean acidification in the interior of the western North Pacific subtropical region, Abstact for $2^{\text {nd }}$ International Ocean Research Conferece.

Takatani, Y., D. Sasano, T. Nakano, T. Midorikawa, and M. Ishii, 2012: Decrease of dissolved oxygen after the mid-1980s in the western North Pacific subtropical gyre along the $137^{\circ} \mathrm{E}$ repeat section, Global Biogeochem. Cycles, 26, GB2013, doi:10.1029/2011GB004227.

Talley, L. D., 2008. Freshwater transport estimates and the global overturning circulation: shallow, deep and throughflow components. Progress in Oceanography, 78, 257-303, doi:10.1016/j.pocean.2008.05.001.

Talley, L. D., 2009: Review of ocean temperature, salinity and oxygen changes in the Pacific and subtropical southern hemisphere. 2009 IOP Conference Series: Earth Environ. Sci.. 6, 032009, doi:10.1088/1755-1307/6/3/032009.

Talley, LD. 2013. Closure of the global overturning circulation through the Indian, Pacific and Southern Oceans: schematics and transports. Oceanography, 26(1), 80-97, http://dx.doi.org/10.5670/oceanog.2013.07

Tanhua T, N.R. Bates, A. Körtzinger, 2013a. The marine carbon cycle and ocean carbon inventories. Siedler, G., Griffies, S., Gould, J. and Church, J. (Eds.): Ocean Circulation and Climate, 2nd Ed. A 21st century perspective, Academic Press, pp 787-815, doi.org/10.1016/B978-0-12-391851-2.00030-1.

Tanhua, T., D. W. Waugh, and J. L. Bullister, 2013b: Estimating changes in ocean ventilation from early 1990s CFC-12 and late 2000s SF 6 measurements. Geophys. Res. Lett., 40, 927-932, doi:10.1002/grl.50251. 
Tanhua, T., D. W. Waugh, and D. W. R. Wallace, 2008: Use of $\mathrm{SF}_{6}$ to estimate anthropogenic $\mathrm{CO}_{2}$ in the upper ocean. J. Geophys. Res., 113, doi:10.1029/2007JC004416.

Thompson, D. W. J., J. M. Wallace, and G. C. Hegerl, 2000: Annular modes in the extratropical circulation. Part II: Trends. J. Climate, 13, 1018-1036. doi: 10.1175/15200442(2000)013<1018:AMITEC>2.0.CO;2

van Heuven, S. M. A. C., M. Hoppema, O. Huhn, H. A. Slagter, H. J. W. de Baar, 2011: Direct observation of increasing $\mathrm{CO}_{2}$ in the Weddell Gyre along the Prime Meridian during 1973-2008. Deep-Sea Res. II, 58, 2613-2635, doi:10.1016/j.dsr2.2011.08.007.

Walker, S. J., R. F. Weiss, and P. K. Salameh, 2000: Reconstructed histories of the annual mean atmospheric mole fractions for the halocarbons CFC-11, CFC-12, CFC-113, and carbon tetrachloride. J. Geophys. Res., 105, 14285-14296, doi:10.1029/1999JC900273.

Wanninkhof, R., S. C. Doney, J. L. Bullister, N. M. Levine, M. Warner, and N. Gruber, 2010: Detecting anthropogenic $\mathrm{CO}_{2}$ changes in the interior Atlantic Ocean between 1989 and 2005. J. Geophys. Res., 115, C11028, doi:10.1029/2010JC006251.

Wanninkhof, R., G.-H. Park, T. Takahashi, R. A. Feely, J. L. Bullister, and S. C. Doney, 2013a: Changes in deep-water $\mathrm{CO}_{2}$ concentrations over the last several decades determined from discrete $\mathrm{pCO}_{2}$ measurements. Deep-Sea Res. I., 74, 48-63, doi:10.1016/j.dsr.2012.12.005.

Wanninkhof, R., G.-H. Park, T. Takahashi, C. Sweeney, R. Feely, etal, 2013b: Global ocean carbon uptake: Magnitude, variability and trends. Biogeosciences, 10, 19832000, doi:10.5194/bg-10-1983-2013.

Warner, M. J., and R. F. Weiss, 1985: Solubilities of chlorofluorocarbons 11 and 12 in water and seawater. Deep-Sea Res., 32, 1485-1497, doi: 0.1016/0198-0149(85)900998.

Waterhouse, A., J. A. MacKinnon, J. D. Nash, M. H. Alford, E. Kunze, et al., 2014: Global patterns of diapycnal mixing from measurements of the turbulent dissipation rate. $J$. Phys. Oceanogr., 44, 1854-1872, doi:10.1175/JPO-D-13-0104.1.

Waters, J.F., F.J. Millero, and C.L. Sabine, 2011. Changes in South Pacific anthropogenic carbon. Global Biogeochem cycles 25, GB4011, doi: 10.1029/2010GB003988. 
Waugh, D. W., T. M. Hall, and T. W. N. Haine, 2003: Relationships among tracer ages. J. Geophys. Res., 108, doi:10.1029/2002JC001325.

Waugh, D. W., F. Primeau, T. Devries, and M. Holzer, 2013: Recent changes in the ventilation of the Southern Oceans. Science, 339, 568-570, doi:10.1126/science.1225411.

Whalen, C. B., L. D. Talley, and J. A. MacKinnon, 2012: Spatial and temporal variability of global ocean mixing inferred from Argo profiles. Geophys. Res. Lett., 39, L18612, doi:10.1029/2012GL053196.

Whalen CB, MacKinnon JA, Talley LD, Waterhouse AF. 2015. Estimating the mean diapycnal mixing using a finescale parameterization. J. Phys. Oceanogr., 45, 11741188

Whitney, F. A., H. J. Freeland, and M. Robert, 2007: Persistently declining oxygen levels in the interior waters of the eastern subarctic Pacific. Prog. Oceanogr., 75, 179-199, doi:10.1016/j. pocean.2007.08.007.

Whitney F.A., S. J. Bograd, and T. Ono, 2013. Nutrient enrichment of the subarctic Pacific Ocean pycnocline. Geophys. Res. Lett. 40: 2200-2205, doi:10.1002/grl.50439.

Wunsch, C., and P. Heimbach, 2013: Two decades of the Atlantic meridional overturning circulation: Anatomy, variations, extremes, prediction, and overcoming its limitations. J. Climate, 26, 7167-7186, doi:10.1175/JCLI-D-12-00478.1.

Yashayaev I. 2007. Hydrographic changes in the Labrador Sea, 1960-2005. Prog. Oceanogr., 73, 242-76. doi:10.1016/j.pocean.2007.04.015

Yool, A., E. E. Popova, A. C. Coward, D. Bernie, and T.R. Anderson, 2013: Climate change and ocean acidification impacts of lower trophic levels and the export of organic carbon to the deep ocean. Biogeosciences, 10, 5831-5854, doi:10.5194/bg10-5831-2013.

Zamora, L., A. Landolfi, A. Oschlies, D. Hansell, H. Dietze, and F. Dentener, 2010. Atmospheric deposition of nutrients and excess $\mathrm{N}$ formation in the North Atlantic. Biogeosciences 7: 777-793.

Zhang, J.Z., C. M. Mordy, L. I. Gordon, A. Ross, and H. E. Garcia, 2000. Technical Comment on Temporal trends in deep ocean Redfield ratios. Science 289: 1839a. 


\section{Figures}
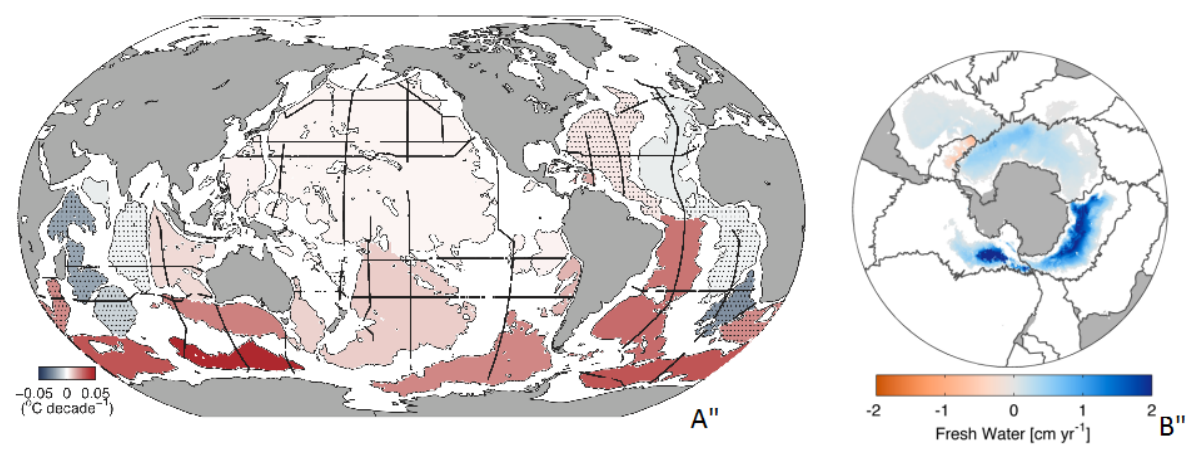

Figure 1. (a) Rates of temperature change below $4000 \mathrm{~m}$ (colors, see key) in deep basins (thin gray lines) estimated from CLIVAR/GO-SHIP repeats of WOCE hydrographic sections (black lines). Basins where changes are not statistically different from zero at 95\% confidence are stippled. (Rhein et al. 2013, based on Purkey \& Johnson 2010). (b) Rates of fresh water inventory change (colors, see key) owing to water-mass $(\theta-S)$ changes within $\mathrm{AABW}\left(\theta<0^{\circ} \mathrm{C}\right)$ in deep basins (thin gray lines) again estimated from repeat hydrographic sections. Adapted from Purkey \& Johnson (2013). 

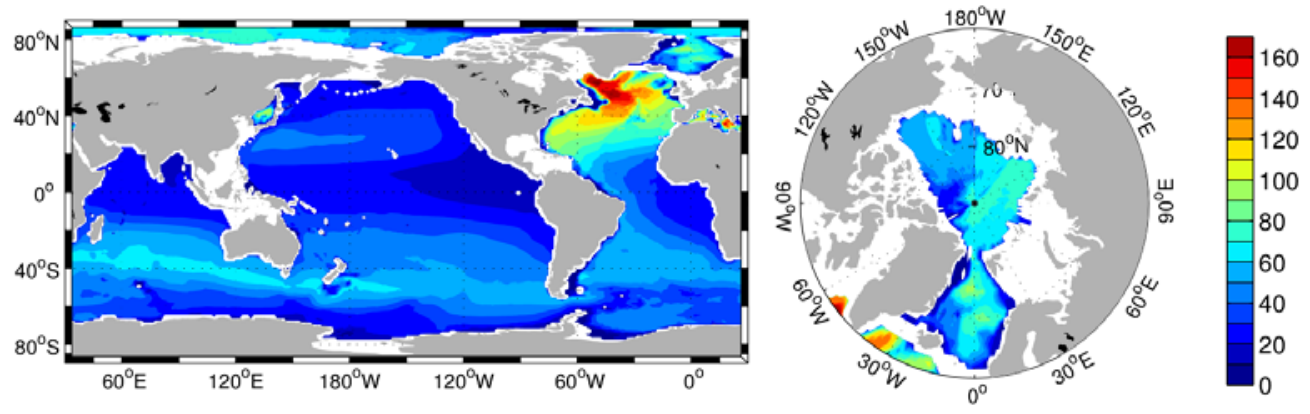

Figure 2. Compilation of the 2010 column inventories $\left(\mathrm{mol} \mathrm{m}^{-2}\right)$ of anthropogenic $\mathrm{CO}_{2}$ : the global Ocean excluding the marginal seas $150 \pm 26$ PgC (Rhein et al. 2013; updated from Khatiwala et al. 2009). From Khatiwala et al. (2013). 

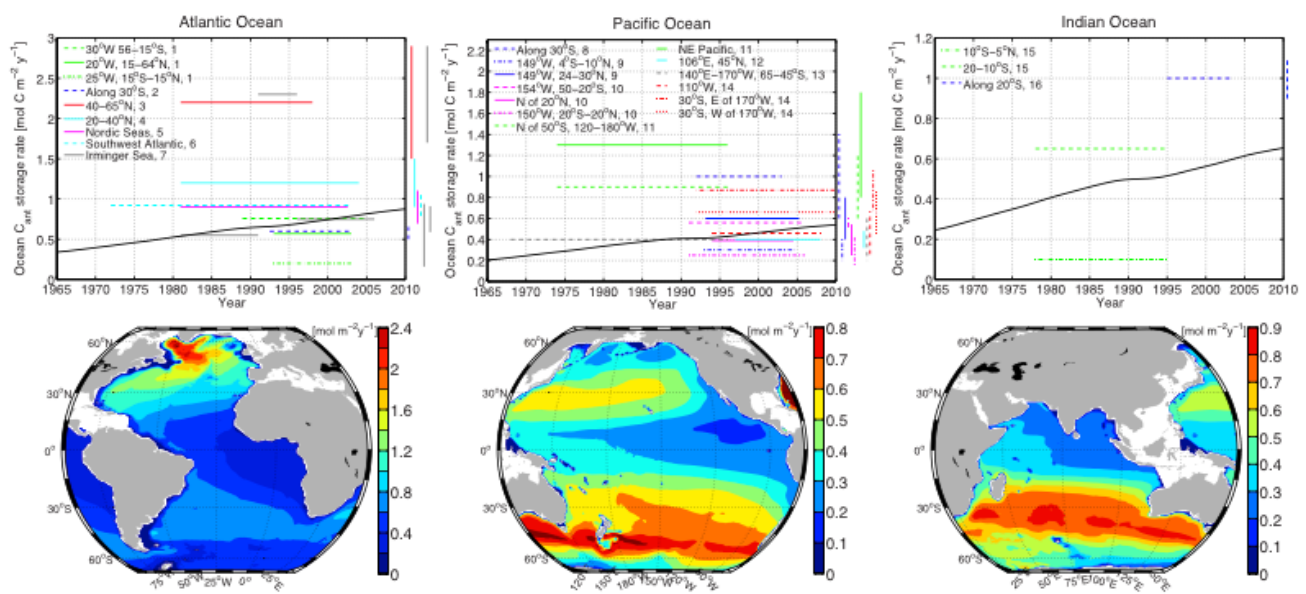

Figure 3. Decadal storage rates of anthropogenic carbon ( $\mathrm{mol} \mathrm{m}^{-2} \mathrm{yr}^{-1}$ ), as observed from repeat hydrography cruises. (Upper panels): The horizontal lines depict the measurement intervals bracketed by repeat hydrography cruises. Measurements for the Northern Hemisphere are drawn as solid lines, the tropics as dash-dotted lines, and dashed lines for the Southern Hemisphere; the color schemes refer to different studies. Estimates of uncertainties are shown as vertical bars with matching colors along the right axes. The solid black line represents the basin average storage rate using Green's functions. (Lower panels): Maps of decadal storage rates from a Green’s function inversion averaged over 1980-2005 using data shown in top panels; note the different color scales. (From Khatiwala et al. 2013.) 


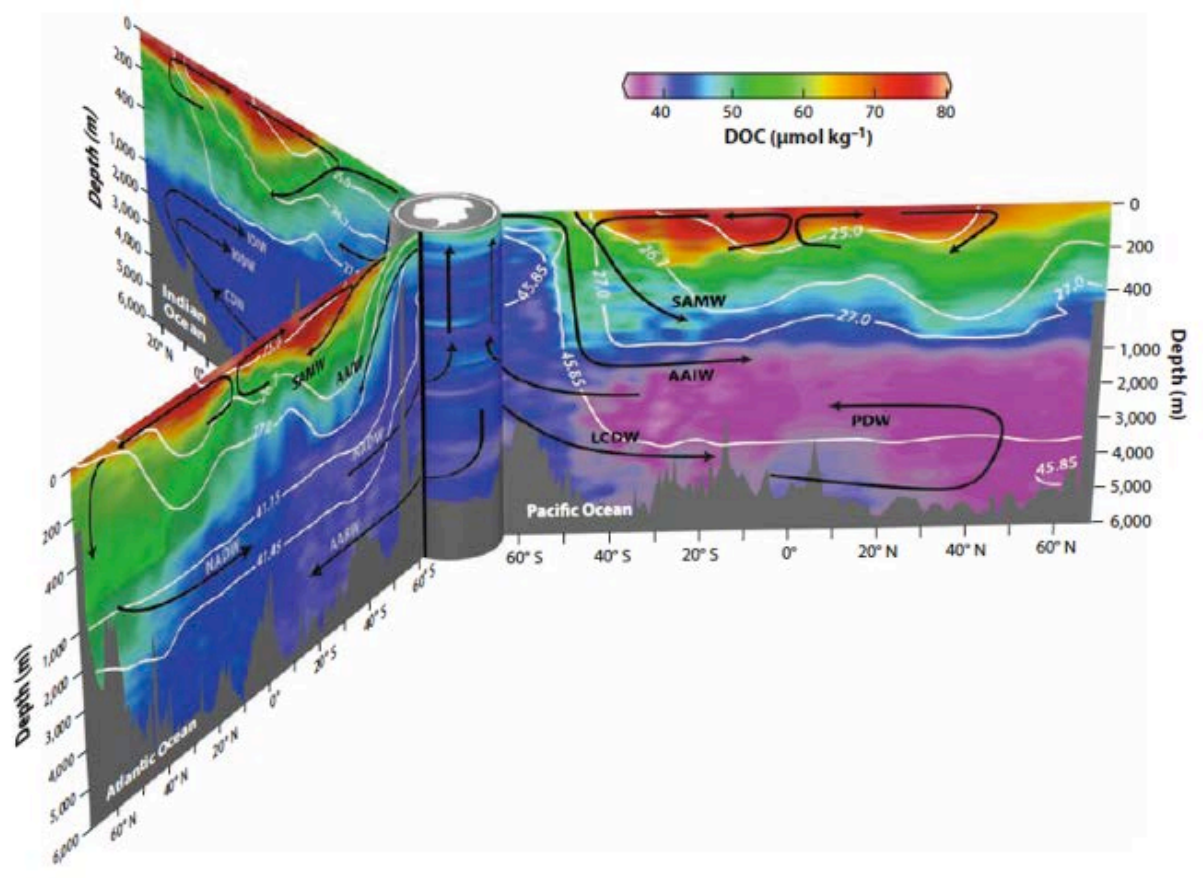


Figure 4. Distributions of DOC ( $\mu \mathrm{mol} \mathrm{kg}{ }^{-1}$ ) in the Atlantic, Pacific, and Indian oceans on GO-SHIP repeat hydrography lines A16, P16, and I8/I9, respectively, with water from all lines connected via the Antarctic Circumpolar Current. Arrows depict water mass renewal and circulation; white lines indicate isopycnal surfaces. Note DOC export in the North Atlantic with North Atlantic Deep Water formation, then DOC loss during deep circulation to the South Atlantic. In the Pacific, there is a northward invasion of relatively DOC-enriched circumpolar deep water along the bottom, slow removal of DOC into the far North Pacific, and return flow of DOC-impoverished water to the south at mid-depths. Modified from Hansell et al. (2009). 

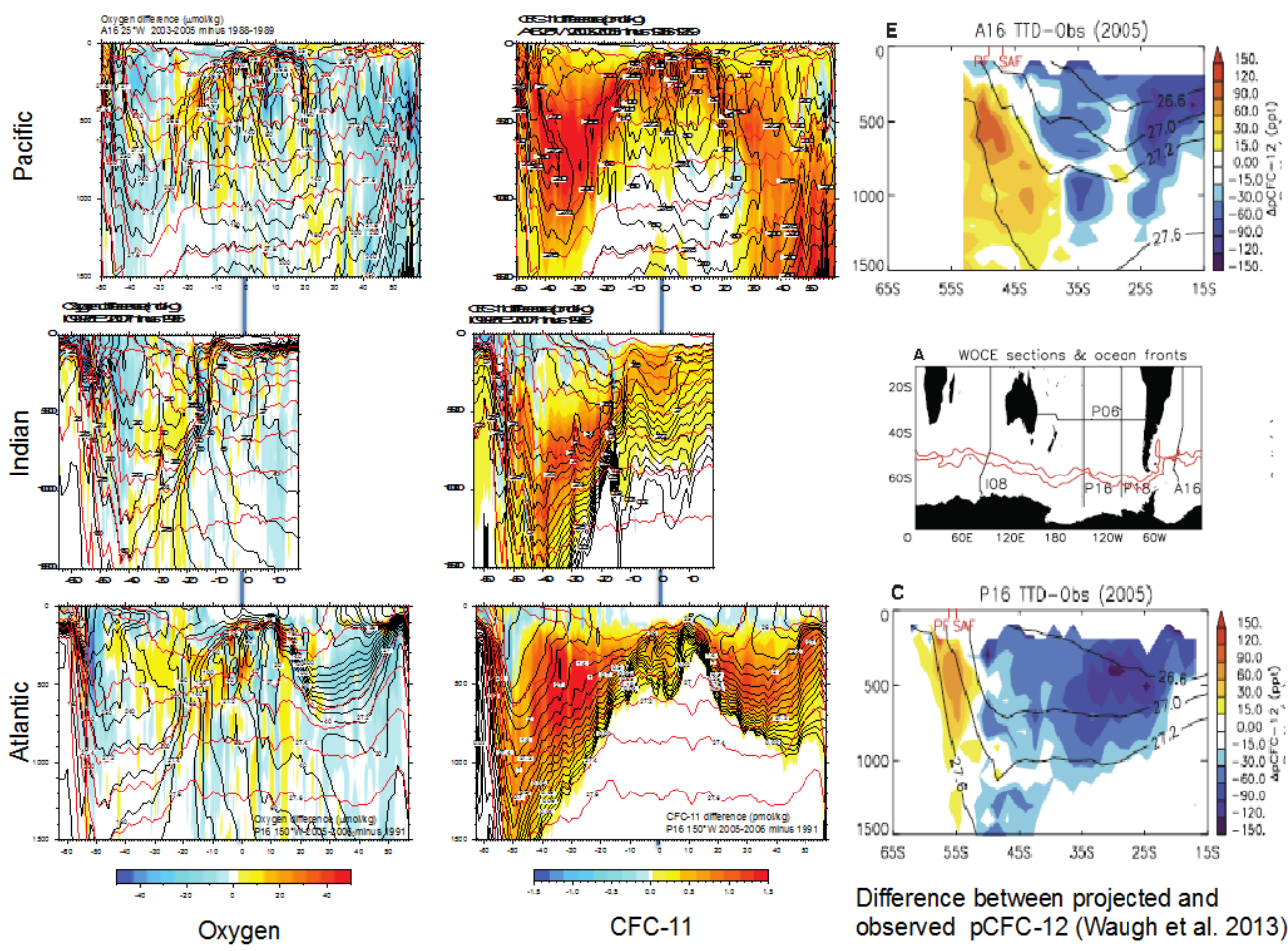

Difference between projected and observed pCFC-12 (Waugh et al. 2013)

Figure 5. Changes from 0 to $1500 \mathrm{~m}$ in (left column) oxygen ( $\mu \mathrm{mol} / \mathrm{kg}$ ) and (middle column) CFC-11 (pmol/kg). (Top row) Pacific at 150W (“P16”; $2005-2006$ minus 1991), (middle row); Indian at $95^{\circ} \mathrm{E}$ (“I8I9”; 2005 minus 1995); (bottom row) Atlantic at 20W (“A16”; 2005-2006 minus 1989). A map of the complete P16, I8I9, and A16 section locations is provided in Supplemental Figure 1. Properties are interpolated to neutral density surfaces, differenced, and then projected back to depth coordinates, using the neutral density from the earlier year for the projection. Thus "heave”, due to vertical migration of the neutral density surfaces, is excluded. Each panel includes overlain contours of neutral density (red contours) and of the property itself from the earlier occupation (black contours).

(Right column) Difference between TTD-predicted and observed pCFC-12 for the 2005 cruises compared with 1991 (P16) and 1989 (A16) (shading). PF and SAF are the Polar Front and Subantarctic Front. Isopycnals (black) are from the earlier occupations of the P16S and A16 sections. The TTD calculations use $\Delta / \Gamma=1.0$ and surface saturation of $90 \%$. Blues indicate that 
there is more pCFC-12 than expected in the 2005 occupation, hence younger water/greater ventilation, and yellows indicate that there is older water/less ventilation than expected. (After Waugh et al. 2013). 

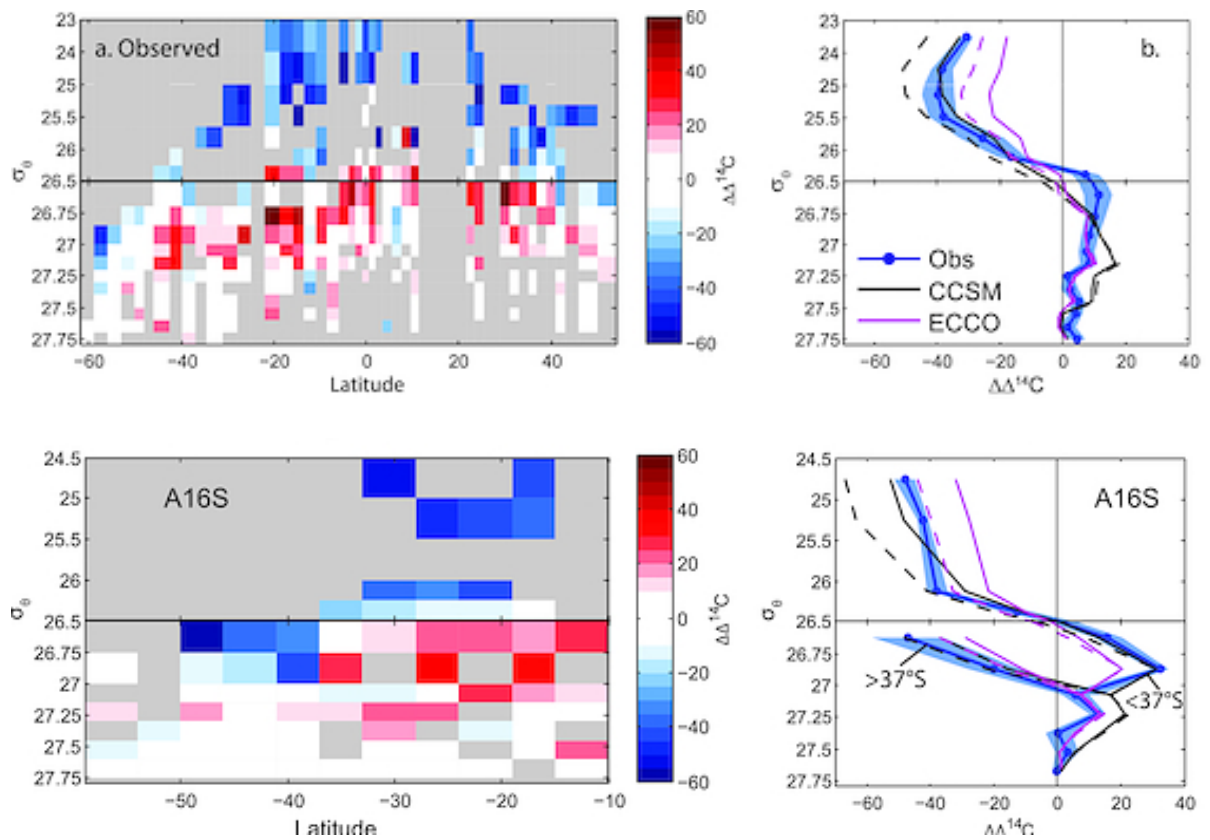

Figure 6. Change in bomb radiocarbon $\Delta^{14} \mathrm{C}$ on isoneutral surfaces for: (top row) Pacific (150 W P16) for 1991 to 2005-2006 and (bottom row) South Atlantic (20 W A16) for 1989 to 2005-2006. Blue (negative) indicates reduction in $\Delta^{14} \mathrm{C}$, and red (positive) indicates increase in $\Delta^{14} \mathrm{C}$. Zonally averaged differences as a function of neutral density are shown in the right panel (“Obs”) along with two model results. From Graven et al. (2012). 